\title{
A Police Café hatása a rendőrség és a közösségek kapcsolatára - 2. rész, interjúelemzés ${ }^{1}$
}

\section{MOLNÁR Katalin²}

„Ahelyett, hogy mindenki más számára érvényesként írnék elő egy olyan maximát, melyet általános törvényül akarok, maximámat a benne rejlö egyetemességigény diszkurzív vizsgálata céljából mindenki más elé kell terjesztenem. A hangsúly áttolódik arról, amit minden egyes ember ellentmondás nélkül általános törvényként akarhat, arra, amit egyetértésben mindenki egyetemes normaként ismerhet el."

Thomas McCarthy ${ }^{3}$

\begin{abstract}
A Police Café módszer magyarországi története idén ötéves. Egyre többen kíváncsiak arra, van-e bármilyen hatása a rendezvényeknek a rendőrség és a közösségek kapcsolatára és ezen keresztül a közös helyi biztonságra. Hogy képet kapjak arról, hogyan gondolkodnak a Cafékról és azok hatásáról, maguk a résztvevők, 2017-2018-ban 121 fös mintán kérdőíves módszerrel kérdeztem meg 27 magyarországi Police Café résztvevőinek véleményét. Baranya megye három, Bács-Kiskun megye kilenc városa, valamint Zugló nyolc rendöri körzete voltak a kutatás terepei. A kérdőíveket elemző tanulmány folytatása a most közreadott 2. rész, amely az ugyanezeken a területeken rendezett Police Cafékban aktívan közremúködő rendőrökkel és civil meghívottakkal készült $7+$ 7 interjút dolgozza fel.
\end{abstract}

Kulcsszavak: közösség, rendörség, Police Café, problémamegoldás, World Café

\section{Előzmények - Police Café kérdőíves kutatás}

2018 nyarán 121 fős mintán kérdőíves módszerrel kérdeztem meg és elemeztem 27 magyarországi Police Café résztvevőinek véleményét. ${ }^{4} \mathrm{~A}$ több mint 400 résztvevő közül a 318 civilt és 69 rendőrt megcélzó kérdőívet a civilek 25, a rendőrök 45\%-a töltötte ki. A kutatás helyszínei azok a területek voltak, ahol Police Café sorozatokat rendeztünk

\footnotetext{
Az ugyanezen témában készített kérdőives kutatás elemzését lásd itt: Molnár (2019).

2 MOLNÁR Katalin, PhD, egyetemi docens, NKE Rendészettudományi Kar, Magatartástudományi és Módszertani Tanszék Katalin MOLNÁR, PhD., associate professor, NUPS Faculty of Law Enforcement

https://orcid.org/0000-0001-7271-5177, molnar.katalin@uni-nke.hu

3 McCarthy (1980) 371.

4 Ezenkívül még 3 rendőrkávéházat tartottunk Csongrád megyében 2016 tavaszán, ami így összesen 31 alkalmat jelent. Ezt a hármat azonban nem vettem bele a vizsgálatba, mert azok nem tekinthetők sorozatnak.
} 
az elmúlt öt évben: az elsőt 2014. június 2-án Pécsett, az utolsót 2017. június 20-án Budapesten, Zuglóban. A helyszínek Baranya megye három, Bács-Kiskun megye kilenc városa, valamint Zugló nyolc rendőri körzete voltak. ${ }^{5}$ A lekérdezést Zuglóban 2017 augusztus-szeptemberében, Bács-Kiskun és Baranya megyében pedig 2018 május-júniusában végeztem. A kérdőíveket a Google online űrlapszerkesztő program ${ }^{6}$ segítségével készítettem. ${ }^{7}$

A helyi sajátosságokat is figyelembe véve külön kérdőívet állítottam össze rendőröknek és civileknek. A két célcsoport által adott válaszokat összehasonlítottam. A World Café módszertan eredetéről és Police Caféként való magyarországi adaptálásáról, történetéről szóló rövid bevezetőt követően a kutatás célját, módszereit, célcsoportjait bemutató módszertani fejezet megadta azt a szövegkörnyezetet, amelyben a kérdőíves felmérés eredményei elhelyezhetők, értelmezhetők. A tanulmányból megtudható, hogy a 27 alkalommal együtt kávézó válaszadó civilek és rendőrök milyen korúak, neműek, milyen beosztásokban dolgoznak, milyen az iskolázottságuk, szakmájuk, tapasztalatuk. A fejezetek, amelyek mentén a válaszokat bemutattam és elemeztem, az alábbiak voltak:

- $\quad$ a válaszadók módszerről meglévő korábbi ismeretei;

- a válaszadóknak a Police Cafék szervezésével és hangulatával kapcsolatos véleményei;

- $\quad$ a Police Cafék szakmai hozadékainak megítélése;

- $\quad$ egy lehetséges következő Police Cafén való részvételi szándék és témajavaslatok;

- a Police Café kritikája;

- a rendőrök véleménye a módszertani képzésről, saját szerepükről, a jó Police Café hozzávalóiról;

- Police Café csak rendőröknek?

Néhány tételmondat a kérdőíves kutatás eredményeiből:

- Minél több helyi szakmai tapasztalattal bírnak a házigazda és témagazda rendőrök, a Police Cafék lebonyolítása annál jobb kezekben van.

- A módszertan fontos része a vendéglátás. Ezért a helyszínek kijelölése, az érintettek elemzése és a meghívandók kiválasztása, megszólítása, az esemény megszervezése, a helyiség berendezése, a kávé és a szemléltető eszközök bekészítése, a vendégek fogadása, leültetése a képzésen kiemelt téma. A válaszadók a Cafékban mindezekkel elégedettek voltak.

- A vendégek és a rendőrök is teljes mértékben úgy érzik, a Café módszer mindenkinek lehetőséget biztosít a megszólalásra.

\footnotetext{
Az összes Police Café és más típusú Café alkalom teljes listája időrendbe sorolva megtalálható itt: http://policecafe.hu/ rendorkavehazak/ (2019. 07. 01.). Tartalmi leírásuk pedig szubjektív moderátori beszámolókban itt olvasható: http:// policecafe.hu/blog/ (2019. 07. 01.)

www.google.hu/intl/hu/forms/about/ (2019. 07. 01.)

A kérdőívek az alábbi linken érhetők el: http://policecafe.hu/police-cafe-extra-5-hogyan-hat-a-rendorkave/ (2019. 07. 01.)
} 
- Valamilyen mértékű szemléletváltozást saját magán a válaszadó civilek 92, a rendőrök 81\%-a tapasztalt. Talán nem túlzás ebből a számból arra következtetni, hogy a szemléletformálásnak a Police Café hatékony módja.

- A válaszoló rendőrök $100 \%$-a pozitív benyomásokat szerzett a Cafékban jelen lévő civilekről, az általuk képviselt szervezetekről és intézményekről, ami jó jele a rendőrök civilek felé nyitásának. A civilek $94 \%$-a is egyértelműen pozitívan nyilatkozott a Cafékban megismert rendőrökről, 87\%-uknak pedig javult a véleménye a rendőrségről is.

- A válaszadók elsöprő többsége egyértelműen vagy kisebb-nagyobb megkötésekkel ajánlaná másoknak is a Police Cafén való részvételt.

- A rendőröknek a rendezvények előtti véleménye a programsorozat után egyöntetűen pozitívan változott. Egyetlen rendőr sem erősítette meg a korábban felmerülő fenntartásait.

- A Police Cafénak a rendőrség belső szervezeti viszonyaira, a kollégák, illetve a vezetók és a beosztottak közötti kapcsolatokra is van jótékony hatása.

- És végül az is kiderült, hogy az alábbi téren van még tennivaló: a módszertan maradéktalan betartásának hangsúlyozása; a sajtónyilvánosság növelése; a rendezvények időtartamának helyi sajátosságokra szabása, a Cafék nyomán született probléma- és helyzetmegoldások visszacsatolása a közösségnek. ${ }^{8}$

\section{Police Café interjús kutatás}

A kérdőívek elemzése közben elhatároztam, hogy a résztvevők véleményét félig strukturált interjúkkal is kikérem. Ezeknek a felvétele 2018 júliusa és októbere között történt, többnyire az interjúalanyok irodájában, zavartalan körülmények között. Egy-egy beszélgetés időtartama átlagosan 40 perc volt. Az interjúkat a megkérdezettek beleegyezésével diktafonon rögzítettem, ám azok szövegét szó szerint nem jegyeztem le. A válaszokat strukturálva kivonatolom, és úgy vonom le belőlük a következtetéseimet. Helyenként szó szerint idézem a nyilatkozókat, amikor fontos, hogy a saját szavaikkal adjam vissza gondolataikat.

\section{Az interjús kutatás helyszínei}

A három helyszín, ahonnan az interjúalanyokat kiválasztottam, természetesen ugyanaz, mint a kérdőíves kutatásé volt. Mivel a Police Café módszertana azt vallja, hogy a párbeszéd során felvetett kérdéseket kimondottan a helyi sajátosságokra kell építeni, ezért érdemes lenne részletesebben bemutatni és összehasonlítani a három földrajzi területet. Ám kutatásomnak sem a kérdőíveket, sem pedig az interjúkat elemző része nem terjedt ki az érintett lokalitások szociológiai és kriminológiai sajátosságainak feltérképezésére

http://policecafe.hu/police-cafe-extra-5-hogyan-hat-a-rendorkave/ (2019. 07. 01.) 
és analízisére, miközben ezek azért érdekes szakmai következtetések levonására is módot adnának. Ez azonban egy külön tanulmányt érdemelne.

Annyit azonban e helyütt is mindenképpen érdemes megjegyezni, hogy egy település kriminológiai mutatói (mennyi bủncselekmény, szabálysértés történik, milyen konfliktusok jellemzőek, ezek közül mennyi az aránya azoknak, amelyeket a rendőrség és a lakosság együttmúködésével jó eséllyel meg lehetne előzni vagy kezelni) segítenek abban, hogy a legadekvátabban tudjuk kiválasztani azokat a településeket, ahol a Police Café módszere a beavatkozás hatékony módja lehet.

$\mathrm{Az}$ 1. táblázatban látható, hogy a vizsgált településeken dolgozó rendőröknek mekkora a munkaterhük (azaz hány lakos biztonságát kell „menedzselniük”). Ennyi embert nyilvánvalóan lehetetlen kontrollálni - amely szándék a klasszikus rendészeti felfogásnak ugyan megfelel -, azonban együttmúködni velük, főleg ha jól megszervezzük az ezt biztosító párbeszédet, nagyon is lehetséges. Ez utóbbira alkalmas a Café módszer, amelynek a hatékonyságát hivatott alátámasztani a tanulmány.

$\mathrm{Az}$ 1. táblázatból az is megtudható, hogy a három területen élő lakosok és ott dolgozó rendőrök mekkora arányát tudtuk bevonni az innovatív párbeszédbe. Ez érzékelteti a számomra legizgalmasabb kérdést: Ha egy szűk körben - az érintett területeken mindössze 410 civil vendéggel kávéztak a rendőrök - ilyen hatásokat lehetett kiváltani, akkor az adott lokalitásnak a rendőri illetékességi területen élő teljes lakosságát bevonó sorozattal milyen eredményeket lehetne elérni? Ez illuzórikus elképzelés, de nincs is szükség mindenkinek a bevonására, de azokéra, akik a biztonságteremtésben érintettek, nagyon is. Hogy kik ők, azt az érintettek elemzése ${ }^{9}$ módszerének tudatos alkalmazásával mindenhol jól körül lehetne határolni.

1. táblázat: A vizsgált területek lakosságszámának (2018. január) és rendőri létszámának (2018. november) aránya és a Police Cafékban részt vevő civilek és rendőrök száma. ${ }^{10}$ Forrás: www.ksh.hu/docs/hun/xstadat/xstadat_eves/i_wdsd003b.html (2019. 07. 01.).

A városi lakossági létszámadatok forrása: www.nyilvantarto.hu/hu/statisztikak (2019. 07. 01.)

\begin{tabular}{|l|c|c|c|}
\hline & Bács-Kiskun megye & Baranya megye & $\begin{array}{c}\text { XIV. kerület } \\
\text { Zugló }\end{array}$ \\
\hline Lakosságszámok (fő) & 505602 & 363721 & 114862 \\
\hline Rendőri létszámok (fő) & 1865 & 1622 & 158 \\
\hline 100 ezer lakosra jutó rendőrök száma (fő) & 369 & 446 & 137 \\
\hline A Police Cafékban részt vevő civilek száma (fő) & 170 & 90 & 22 \\
\hline A Police Cafékban részt vevő rendőrök száma (fó) & 26 & 21 & 150 \\
\hline
\end{tabular}

Fenyvesi (2012)

10 A rendőri létszámadatokért köszönet az interjúban szereplő rendőrkapitányoknak. 
A vizsgált települések összehasonlításának más szempontból is van jelentősége. Nem mindegy ugyanis, hogy a három eltérő jellegú és méretű közösség (Pécs, Zugló és Kiskunhalas) életében milyen szerepet játszik a helyi rendőrkapitányság múködése. A kapitányokkal történt interjúbeszélgetések közben felvetődött bennem a kérdés: Vajon ez a szerep van-e hatással egy-egy rendőrkapitány szakmai tevékenységére, vagy fordítva: a rendőrkapitány (a nyilatkozók esetében hangsúlyozom: szolgáltató, problémára és közösségre orientált rendészeti) attitűdje terjed-e ki meghatározóan a rendőrkapitányság belső szervezeti viszonyaira, majd abból fakadóan szükségszerűen a helyi rendőrök közösséggel való kapcsolatának a minőségére? Nyilvánvaló, hogy a hatásmechanizmus oda-vissza érvényesül, mégis rendőröket, kiváltképpen rendőrvezetőket oktatóként az utóbbinak tulajdonítok nagyobb jelentőséget. Főleg, ha a szerepüket biztonsági menedzserként értelmezzük.

Természetesen az is fontos tényező, hogy mekkora és milyen összetételü településnek a rendőrkapitányságát vezeti valaki. Ebben az összefüggésben különösen érdekes összevetni a két vidéki nagyvárost (Pécset és Kiskunhalast), és a budapesti kerületek között igencsak nagynak számító Zuglót. De nem annyira a méret, inkább a lakosságszámok beszédesek. Pécs megyei jogú város lakossága (kb. 145 ezer fő) nem sokkal több, mint Zuglóé (közel 115 ezer fő). Ehhez képest Kiskunhalas a mintegy 28 ezer fős lakosságszámával kicsinek számít. Nyilvánvalóan nehezebb „mindenkit ismerni” a két előbbiben, mint az utóbbiban.

A három város kriminológiai jellemzőit összehasonlítva nem látunk nagy különbségeket. Mindegyiknek meglehetősen heterogén összetételű a lakossága. Vannak kimondottan elit, illetve elmaradottabb környékek, veszélyeztetettebb társadalmi rétegek, fiatalok és idősek, és ugyancsak mindenhol probléma a közlekedés vagy éppen a köztisztaság helyzete mint a helyiek biztonságát befolyásoló tényező.

A vizsgált települések ezenfelül közigazgatásilag is különböznek egymástól: a főváros egyik kerületének lenni sokkal nagyobb függőséget jelent, mint egy megyei jogú városnak vagy egy alföldi mezővárosnak. A rendőrségi hierarchiában sem egyenértékű, hogy a budapesti vagy az adott megye rendőrfőkapitányának irányítása alatt kell dolgoznia a helyi vezetőnek. Mindezekről érintőlegesen volt szó a rendőrkapitányokkal folytatott interjúkban is, de ennél részletesebben ennek kifejtésére nincs sem mód, sem pedig szükség. A későbbiekben azonban ez is fontos szempont lehet a Police Cafék hatásvizsgálatához, hiszen mindezek alapján választ kaphatunk arra a kérdésre, hogy hol és mire lehet használni a módszert.

\section{Az interjús kutatás célcsoportja}

Összesen 14 fővel készült interjú. Kivétel nélkül mindegyikük megtisztelőnek vette, hogy elmondhatta a véleményét, kifejezetten nyíltak és közlékenyek voltak. Egy részük korábban a kérdőívet is kitöltötte, de ők is örültek, hogy a személyes interjúban bővebben is kifejthetik gondolataikat. 
Annak érdekében, hogy amennyire lehet, kiegyenlítettek legyenek a különböző nézőpontok, a megkérdezettek között fele-fele arányban vannak civilek és rendőrök. Mindannyian olyanok, akik a három vizsgált területen rendezett Police Cafékon több alkalommal is jelen voltak. Némelyikük az adott körzetben rendezett mindegyik Caféban részt vett. Fontosnak tartottam azokat kérdezni, akik különböző dinamikákat, hangulatokat tapasztalhattak meg, így nekik is van összehasonlítási alapjuk, teljesebb a képük. (Egyetlen kivétel egy televíziós szerkesztő, aki csak egy alkalommal volt vendég.) Minél többször vesz részt valaki egy ilyen rendezvényen, nyilvánvalóan annál árnyaltabban éli át az ott zajló beszélgetéseket, annál mélyebbre lát a problémák felvetése, elemzése során, és valószínűleg annál nagyobb mértékben tud részesévé válni a megoldásoknak is.

A részvétel státusza, azaz, hogy valaki házigazda, témagazda vagy vendég volt, szintén lényeges, mivel ennek mentén nemcsak más nézőpontból tekint a rendezvényekre, de azok menetére gyakorolt hatása is más mértékú. A házigazdának (ezt a tisztet jellemzően a helyi rendőrkapitány és az adott lokalitás őrsparancsnoka vagy körzeti megbízottja töltik be) inkább csak protokolláris feladatai vannak, megnyitja és bezárja a rendezvényt, összegzi az elhangzottakat. Témagazdaként a kisebb asztaltársaságok beszélgetéseit kell mederben tartani, amely feladatot a helyi rendőrök látják el, és ehhez kapnak módszertani felkészítést az egynapos képzésen. A nagyobb felelősség az ő vállukon van, hiszen ahogyan a témák moderálását végzik, annak megfelelően érzik jól magukat és aktivizálódnak a beszélgetőpartnerek. Vendégként a meghívott civilek mindegyike szabadon, az igényének megfelelően aktívabban vagy visszafogottabban vehet részt a különböző témákról szóló beszélgetésekben.

Az interjúk során mindhárom kategóriába tartozók elmondhatták a saját szerepükben átélt élményeiket, amelyeket a részvétel státusza mentén elemzek. A házigazdák, témagazdák és vendégek megoszlása az összesen 14 interjúalany között az alábbi volt: házigazda rendőr - 3 fő; témagazda rendőr -4 fö; civil vendég -7 fő.

A vizsgált időszakban (2014. június 2. és 2017. június 20. között) rendezett 27 Police Caféban a Bács-Kiskun megyei rendőrök összesen 7 városban 12 alkalommal kávéztak 170 civillel, de a két civil interjúalanyt a legaktívabb városból, Kiskunhalasról választottam, ahol a 12-ből 3 Cafét rendeztek. Baranya megyében a vizsgált időszakban 3 városban volt összesen 7 Police Café rendezvény, ebből 5 alkalommal Pécsett, ami mintegy 70 civil résztvevőt érintett. Közülük választottam 3 interjúalanyt. Zuglóban pedig a 2017-es Café sorozattal mind a 8 rendőri körzetet lefedtük, ami azt jelenti, hogy a helyi rendőrökkel összesen 150 szakember beszélgetett, közülük pedig 2 adott interjút.

A válaszadók életkorára nem kérdeztem rá, de körülbelül 35 és 65 év közöttiek, mindannyian aktívak, és meglehetősen jelentős élet- és szakmai tapasztalattal, helyés személyismerettel rendelkeznek. Személyiségük érett, értékrendjük kialakult, érdekérvényesítő képességük nagyon jó, a problémákra érzékenyek, a helyi közélet és kiemelten a biztonság terén meglévő tájékozottságuk átlagon felüli, fellépésük határozott, kommunikációjuk asszertív, adekvát. 
Beosztásukra nézve felső- és középvezetők és beosztottak is vannak köztük. Az egy tiszthelyettes körzeti megbízottat leszámítva felsőfokú végzettséggel rendelkeznek, némelyikük többdiplomás.

A rendőrök között tiszt és tiszthelyettes, vezető és beosztott egyaránt szerepel. Munkakörük: három kapitány, egy őrsparancsnok, egy bűnmegelőzési alosztályvezető, egy bủnügyi osztályvezető-helyettes és egy körzeti megbízott. Az általuk képviselt szakterületek is változatosak: bűnügy, közrendvédelem és bűnmegelőzés. Ketten a zuglói, ketten a kiskunhalasi, hárman pedig a pécsi rendőrkapitányság állományába tartoznak.

A civil interjúalanyok közül ketten Zuglóban, ketten Bács-Kiskun megyében, hárman pedig Pécsett élnek és dolgoznak. Igyekeztem úgy kiválasztani őket, hogy az általuk képviselt szakterületek a helyi közösség minden lényeges szegmensét lefedjék. Az alábbiakban felsorolom annak a hét szakembernek a beosztását, akikkel interjú készült (mindegyiküknél zárójelben az a szám látható, ahány alkalommal részt vettek Police Caféban): egy család- és gyermekjóléti központ vezetője (6), egy egészségügyi intézmény igazgatója (3), egy civil szervezet, konkrétan egy drogellenes közhasznú alapítvány szakmai vezetője (2), egy megyei jogú város polgármesteri hivatalának közbiztonsági referense (4), egy megyei polgárőr szövetségi elnök (2), egy nagy szálloda biztonsági igazgatója (3), illetve egy regionális televízió szerkesztő riportere (1).

\section{Az interjúk elemzése}

\section{A házigazda rendőrök véleményei}

A házigazda szerepét minden általam moderált Police Caféban - egy fővárosi kerületi, illetve két vidéki városról lévén szó - jellemzően a helyi rendőrkapitány és őrparancsnok vagy körzeti megbízott látta el. Ennek nyilvánvalóan az a szimbolikus üzenete, hogy az általuk irányított, felügyelt területen élők szemében többnyire ők a helyi biztonság kiemelt felelősei.

A rendőrségen belüli hierarchiának, illetve a szakmai kompetenciáiknak megfelelően a protokolláris sorrend minden esetben úgy alakult, hogy elsőként a kapitány, majd az őrsparancsnok/körzeti megbízott üdvözölte a vendégeket. A kapitány a nagyobb (kerületi és városi), az őrsparancsnok és a körzeti megbízott a kisebb (városrészi, körzeti) lokalitás szintjén érzékeli a biztonsággal kapcsolatos helyzetet, ennek megfelelően így is beszélnek róla. Tény, hogy egy városi rendőrkapitány vezetői tevékenységébe már az egész közösség biztonságának a „menedzselése” - az azért felelős szakemberek összefogása - is beletartozik. Ehhez hasznos segítség számukra a Police Café metódusa. Az interjúkban ez a nézőpontkülönbség egyértelműen megmutatkozott, ezért külön mutatom be a véleményeiket.

Ezen a ponton érdemes visszautalni arra, amit Az interjús kutatás helyszínei alfejezetben a vizsgált települések sajátosságairól olvashattunk, mert nagyon fontos, hogy 
ezt a „biztonságmenedzsmentet”" milyen helyi adottságok és személyi feltételek mellett kell múködtetni.

\section{A házigazda rendőrkapitányok véleményei}

Mindhárom megkérdezett rendőrkapitány több évtizedes bűnügyi szakmai múlttal rendelkezik, amelyet kifejezetten az adott földrajzi területen szerzett. A zuglói kapitány több budapesti kerületben, a másik kettő pedig az adott megyében dolgozott eleinte nyomozóként. Több más jellegű vezetői beosztásban is tapasztalatot szereztek, mielőtt kapitányságvezetői beosztásba kerültek. Ennek a munkának a jelentős részét a rendészet (klasszikusabb szóhasználattal: közrendvédelem) teszi ki, amelybe saját bevallásuk szerint „bele kellett tanulni”. Mindig azt szerették, ha volt feladatuk, kifejezetten ambiciózus, életük és pályájuk legaktívabb szakaszában tartó szakemberek. Egyikük a tanítványom is volt, a másikukkal egy évtizede rendszeres szakmai kapcsolatot tartok. Szakmailag képzettek, és mind a közösségre, mind a problémákra átlagon felül nyitottak. Szociálisan és morálisan is érzékeny, integráns személyiségek, kitűnő kommunikációs készséggel és pedagógiai érzékkel. Bizonyára ezért is volt számukra magától értetődő, hogy a Police Café rendezvények házigazdájaként azok mindegyikét megnyitották, és ha idejük engedte, végig is beszélgették. Példamutató módon a módszertani felkészítő képzésen és a programsorozatok végén rendezett szupervízión is aktívan részt vettek. A Cafék szakmai hozadékát nemcsak a mostani interjúk apropóján, hanem a megvalósítások során mindvégig reflektíven számba vették. Mindhárman szívesen idézték fel, hogyan találkoztak a módszerrel.

Pécsett, a magyar Police Café „őshazájában” a kapitány hangsúlyozta, hogy számára nem volt kérdés, hogy az élére álljon a kezdeményezésnek. 2012 júliusában a pécsi biztonságot Bándi Kata rendőrségi pszichológus meggyilkolásával kezdődően 2014-ig több kiemelt bűncselekmény révén olyan fokú deficit érte, amely nemcsak a helyi, de az országos közhangulatot is felborzolta. Ezekre 2014-ben már sürgető és lehetőleg innovatív válaszokat kellett adni. A városvezetéssel megkezdődött szokásos hivatali és formális egyeztetések nem bizonyultak eléggé hatékonynak. A megerősített rendőri jelenlét ellenére a lakosság bizalma megrendült a rendőrségben, és a megyei rendőri vezetés belátta, hogy muszáj tenni valamit. A megoldás a bűnmegelőzés irányába kezdett kirajzolódni, és a közösség nagyobb mértékű bevonásában realizálódott. A lakosság tájékoztatása messze nem elegendő, és az sem vezet sehova, ha a civilek csak öntik a rendőrségre a panaszaikat, elégedetlenségüket. Nem ennek kellett tehát nagyobb teret adni, hanem megváltoztatni a kommunikáció jellegét. ${ }^{12}$ Olyan kapcsolat kialakítására volt szükség, amelyben a két fél partnerként van jelen, és főleg a rendőrség válik

\footnotetext{
11 Ehhez a fogalomhoz lásd: Krémer (2018). Ő nem kifejezetten kapitányról és nem menedzsmentről beszél, hanem általában a rendőrről mint a biztonság menedzseréről: „, [A] rendőrt inkább a biztonság (safety) védelmezőjének tekinthetjük (Vitale, 2017: 5). Valójában azonban ennél sokkal több, a biztonság menedzsere, a társadalmi kohézió egyik katalizátora."

12 Bővebben: Gaál-Molnár (2013) 131-140.
} 
befogadóbbá. Az első lépést neki kell megtennie, és ha elég jól csinálja, akkor ő is elkezd valódi visszajelzéseket kapni a saját tevékenységéről.

A Police Café éppen ezt garantálta, mert stílszerúen szinte tálcán kínálkozott a megoldás. Kézenfekvőnek látszott kipróbálni, ${ }^{13}$ és mint mondta: „utóbb kiderült, egyértelműen segített is visszaszerezni a város biztonsággal foglalkozó szakembereinek támogató bizalmát és együttmúködését”. Ez a kapitány szerint azóta is változatlanul fennáll. A jól kiválasztott érintettek meghívásával és megszólításával a rendőrség elérte, hogy ők is kivegyék a részüket a helyi biztonságért való felelősségből, és aktívan tegyenek a rendért. Ezt érezték meg a résztvevők a Cafékban, és a jól felépített módszertannak köszönhetően ez a szándék végigvihetőnek bizonyult. A kapitány vallja: Pécs mérete, jellege és az ezekkel együtt járó biztonsági kihívások tökéletesen alkalmasak arra, hogy a város egy ilyen programnak az ideális helyszíne legyen. A Pécsi Rendőrkapitányság ennek a módszernek az első kipróbálójaként országos mintát is adott. Ha a szorosan vett szakmától nem is, de a civilektől a visszajelzések a kapitány véleménye szerint egyértelműen pozitívak. Büszkeséggel említi, hogy a program révén Pécs ismét bekerült a közösségi rendészet magyarországi jó gyakorlatait felvonultató rendészeti szakirodalomba.

Pécs mint „iskolapélda” már 2004-ben bevonult a hazai közösségi rendészet „történelemkönyvébe”. Az előző rendőrkapitány kezdeményezésére az országban az elsők között vezettek be Pécsett egy kísérleti közösségi rendőri programot „A mi rendőrünk” néven. ${ }^{14}$ Vagyis az a közösségre és problémára orientált típusú rendőri filozófia, ami a Police Cafénak is a kiindulópontja, 2014-ben itt már tízéves múltra tekintett vissza. Ez a szemlélet, az erre való nyitottság nyilvánvalóan sokat számított, hogy egy ilyen program sikerre vihető volt. Az új kollégák sokat ellestek azoktól a régebbi rendőröktől, akik igyekeznek az akkor elsajátított szolgáltatói attitűd szerint dolgozni. A kapitány biztos benne, hogy mindez szerepet játszott abban, hogy a Police Café sorozatnak a szervezeten belüli elfogadottsága náluk sokkal hamarabb megszületett, mint egy olyan rendőrkapitányságon, ahol nem voltak hasonló előzmények.

A kapitány jól tudja, hogy az sem mindegy, hol rendezünk Police Cafét. A pécsi helyszínek kiválasztásában fontos szempont volt, hogy mindenképpen ki kellett menni a rendőrség épületéből, ami nem volt nehéz, mivel mindenhol szívesen fogadták a megkeresést. A meghívottak körének kiválasztása és szükségszerü limitálása volt a következő sarkalatos kérdés, ami szintén jól sikerült. A rendőrségnek minden meghívottal volt kapcsolata, de a vendégek egymás között is elkezdtek új hálózatot szövögetni - és talán ez még fontosabb volt. Már a meghívást is örömmel fogadták, és a beszélgetések során hamar ráéreztek a „kávézás” ízére. A kapitány szerint van ennek a módszernek egy fajta játékossága, aminek egyszerűen nem lehet ellenállni. Az elején a megismerkedés, a végén az összegzés jól keretezik az irányított beszélgetéseket.

\footnotetext{
13 Lásd erről részletesen: Gaál-Molnár (2014) 101-114.

14 Cserép-Molnár (2005) 99-119.
} 
A kiskunhalasi kapitány 2015 októberében egy rendőrvezetők számára rendezett kétnapos konferencián egy előadáson tőlem hallott a Police Caféról. Már a szünetben odajött, hogy kifejezze, mennyire felkeltette az érdeklődését a módszer. Nem sokkal azelőtt, 2015 júliusában bízták meg a kapitányság vezetésével, és bizonyítani szerette volna, hogy rászolgált a bizalomra. Részben befelé, a kollégáknak, részben pedig kifelé, a város civiljeinek: egy közösségre orientált, hatékony, szolgáltató rendőrséget szeretett volna kialakítani és bemutatni. Főleg azért, mert vezetői megbízásának pillanatában nagyon komoly helyi biztonsági deficitekkel szembesült. Azt már akkor tudta, hogy ezt a rendőrség önmagában nem fogja tudni „kezelni”, ahhoz be kell vonni a közösséget. Erre látott jó esélyt ebben a módszerben, és igaza lett. Hamar talált is forrást és közreműködőket a megvalósításhoz, és 2016-ban három, 2017-ben pedig már nyolc Halas Café nyithatott meg a megyében. Kollégáit lassan, de biztosan nyerte meg személyes példamutatásával és aktív közremúködésével, és ők voltak azok, akik az országban elsőként már önállóan, a kapitány moderálásával is rendeztek Police Cafét. ${ }^{15}$

A Police Caféra nagyfokú nyitottságot mutatott a helyi közösség, ami a kapitányt is tovább ösztönözte arra, hogy ezzel a technikával egyre többször éljenek. Ahogyan visszaidézi, rájött, hogy az ötletelés közben a rendőrök mindjárt kapnak visszacsatolást a közösségtől. A vendégek elmondhatják és el is mondják, mégpedig moderáltan és kulturáltan, hogy mi a gondjuk, a rendőrök pedig meghallgatják őket, információkat kapnak tőlük, és ők is informálják őket. Ennél jobb formáját a párbeszédnek ritkán tapasztalt, és saját magát haszonelvű vezetőnek tartva, a módszernek csak az előnyeit látja a saját területén. A civileket megszólítva, megkérdezve kvázi vissza lehet adni nekik a problémakezelést. A rendőrök így velük együtt tudnak kimunkálni megoldásmódokat, illetve ezeket a köreikben elsőként lehet tesztelni.

Régi problémának lája, hogy miközben a rendőrség rengeteget dolgozik, ennek a munkának a hatékonyságát nem tudja jól megmutatni. Ha saját magukat „dicsérik”, az sose jó. Az ideális az lenne, ha az eredményeket a közösség tükrözné vissza. Ezért pedig sokat kell tenni, és elsősorban a kommunikációban, annak minőségi változásában látja a megoldást. A Cafékban a civilek tükre szerinte nagyon őszintén múködik, ami jót tesz a rendőrség önreflexiójának.

A zuglói rendőrkapitányt a program „találta meg”. Mindjárt több epizóddal indítottak, ráadásul az eddigi legnagyobb, 8+1 részes sorozattal. Zugló biztonsága - ahogyan egyébként minden más településé is - természetesen nemcsak a rendőrség kezében van. A kapitány nem győzte elégszer hangsúlyozni, hogy maguknak a lakosoknak és a legkülönbözőbb társadalmi szervezeteknek, intézményeknek ugyanolyan intenzíven kell dolgozniuk nap mint nap azon, hogy a kerület élhető és biztonságos legyen. Közülük is kiemelkedik - és ebben Zuglót igencsak példaértékűnek gondolja - a Zuglói Közbiztonságért Non-profit Kft., amely 2015 óta egyre fejlődő infrastrukturális és szakmai háttérrel támogatja a körzeti megbízottak munkáját a „Szomszédom a rendőr!” program révén. A kapitány megítélése szerint más fővárosi kerületekhez

15 Erról lásd itt: http://policecafe.hu/onkiszolgalo-police-cafe-kiskunmajsan-az-elso-police-cafe-kepeslapom/ (2019. 07. 01.) 
képest a zuglói önkormányzat nagyon komolyan veszi a helyi biztonságot. A zuglói Police Café sorozatra is ennek a programnak az égisze alatt kerülhetett sor. A kft. pályázott a Nemzeti Bűnmegelőzési Tanácshoz, és amikor a kapitányt felkérték a pályázat közremúködő partneréül, nem is gondolkodott a válaszon. Ahogy ő mondta az interjúban: „Melyik kapitány ne örülne, ha egy ilyen lehetőséggel keresik meg?” Jó, hogy ő így gondolja, de azért ez ma még koránt sem általános hozzáállás.

Kiemelte saját „kényelmes” helyzetét, amelynek lényege, hogy a ZKNP szakemberei és kiváltképpen Tomis Károly, a méltán legendás zuglói körzeti rendőr ${ }^{16}$ mindig meg tudják tölteni színvonalas, aktuális és innovatív tartalommal a körzeti megbízotti munkát. Véleménye szerint egyértelmúen ilyennek bizonyult a Police Café is, amely a körzeti megbízottak szabályzatának ${ }^{17}$ máig legfontosabb alapelvét, a lakossággal való rendszeres kapcsolattartást segített kiteljesíteni.

A zuglói kapitány a saját szakmai életútján keresztül érzékeltette, mennyit változott az elmúlt húsz évben annak a módja, hogy a lakosok hogyan keresik meg problémáikkal a rendőrséget. A személyes bejelentések a panaszirodákról a telefon elterjedésével az ügyeletekre terjedtek át, ma viszont egyre inkább az online elérhetőségek használatát tartja jellemzőnek. Ô is tudja, hogy a körzeti megbízotti fogadóóra - jóllehet a szabályzat még mindig előírja ennek meghirdetését - évek óta egyetlen polgárt sem vonz. Helyette a körzeti rendőröket ma már inkább szolgálati mobiltelefonon hívják, amelyhez a készülékeket Zuglóban szintén a ZKNP vásárolta meg és a rendőrség üzemelteti. Vagy az emberek egyszerűen megszólítják az „ő rendőrüket”, hiszen jól ismerik, szinte vagy szó szerint a szomszédjuk.

Vezetővé válásának útjára visszatekintve a zuglói kapitány meglátása szerint az egyes rendőrök hozzáállása, a problémákra való reagálása úgy változott, ahogyan a jogállamiság kiépült. Egyre több tájékoztatási feladatuk lett. Mint hatósági személyek az egyéni együttérzésükön túl szakmailag is többet tudnak tenni az ügyfelek megsegítéséért, különösképpen az áldozatokért. Ezek a szakmai protokollok más emberi hozzáállást, más társas kompetenciákat is igényelnek a rendőrök részéről, amelyekkel szerinte még most sem mindenki rendelkezik. A körzeti megbízottakat szerinte éppen ebbe az irányba kell fejleszteni. A zuglói lakosság nagy része is erre tart igényt, és úgy gondolja, ezzel magyarázható, hogy ebben a kerületben a Police Café típusú kezdeményezésre a civilek ennyire nyitottak voltak. Az általa ismert kerületekkel összehasonlítva az itteni viszonyokat, itt tartja legjellemzőbbnek a lakosság stabilitását, és szerinte ennek köszönhető a „Szomszédom a rendőr!” program sikeressége. Ugyanez egy nagyobb vagy folytonos lakosságcserével és szakembercserével érintett kerületen nem tudna müködni.

16 Lásd: http://policecafe.hu/kommunikacios-potora-avagy-a-megszemelyesitett-korzeti-megbizotti-szabalyzat/ (2019. 07. 01.); www.zknp.hu/buszkek-vagyunk-ra/ (2019. 07. 01.)

17 26/2015. (XII. 9.) ORFK utasítás a körzeti megbízotti szabályzatról; I. fejezet, 2. a): „a Rendőrség állandó, közvetlen kapcsolatának kialakítása és fenntartása az állampolgárokkal, a települési önkormányzatokkal, a helyi lakossági, civil és gazdálkodó szervezetekkel." 
Ő idekerülve megörökölte ezt a programot, de hamar belátta a hasznát, és a mai napig is támogatja. És immár nemcsak ő. A zuglói önkormányzat 2018. október 18-án elismeréseket „adott át az elmúlt időszakban kimagasló teljesítményt nyújtó rendőröknek", és a »Szomszédom a rendőr!« programban nyújtott segítségért a zuglói rendőrkapitányságot elismerő oklevélben részesítette". ${ }^{18}$

A sikernek a kapitány szerint az is záloga, hogy nemcsak a lakosok, de a rendőrök közül is sokan lokálpatrióták. Ez magával hozza, hogy a rendőrök maguk is jól ismerik a kerület hétköznapi problémáit. Meggyőződése, hogy egy Police Café sorozatot csak egy ilyen masszív alapra, egy ilyen jól kiépített és működtetett programra, a lakosok és a rendőrök kölcsönösen meglévő igényére lehet jól felépíteni. Elengedhetetlen, hogy a rendőrök szolgáltatásként tekintsenek munkájukra, elhivatottak legyenek. Illetve az is szükséges, hogy egy ilyen szemléletű kezdeményezés támogatására az önkormányzat is hajlandó legyen. Amint a zuglói példa mutatja, ez valóban így van.

Kapitányként leginkább annak örül, hogy a Budapesti Rendőr-főkapitányság müködésének megszokott, rutinszerű lehetőségeihez képest ezzel a kerület meglehetősen innovatív eszközt tud felmutatni a kapitányságok napi „versenyében”. Például az a hármas ügyeleti rendszer (a 112-es segélyhívó, a 2112233-as ügyeleti telefon, illetve a nyolc körzeti rendőr mobilszámai), amely Zuglóban működik, egyedülálló.

Azt is elmondta, hogy a bejelentések döntő részben nem klasszikusan rendőri reagálást igényelnek. Ezen a ponton érdemes összehasonlítani a három városi kapitány ezzel kapcsolatos attitűdjét, hiszen feltűnő hasonlóságot mutatnak. Mind a pécsi, mind pedig a kiskunhalasi kapitány, bár másként fogalmazva, de ugyanezt erősítették meg, amikor arról beszéltek, hogy a Police Café által kínált innovatív megoldásokat milyen nyitottsággal fogadták. Az interjúkban végighallgatva a kapitánnyá válásukat megelőző szakmai pályafutásukat, szinte magától értetődő, hogy ezt a filozófiát vallják magukénak. Nemcsak tapasztalt búnügyesek, de szakmailag magasan képzettek, így különbséget tudnak tenni a klasszikus (értsd: szankcionáló, elrettentő) és nem klasszikus (értsd: kommunikatív, preventív, szolgáltató) rendőri reagálás között. Ez - tapasztalatom szerint - egyáltalán nem általános a magyar rendőri vezetők körében. Márpedig, aki nem tesz különbséget e két felfogás között, az jó eséllyel a hagyományos büntetés és elrettentés mentén képzeli el egy területi rendőri „szerv” múködését is. A csak ezt a rendőri mentalitást (el)ismerő vezető választani sem tud mást, tehát a Police Café típusú - azaz a nem klasszikus rendőri szerepfelfogás szerint múködő - közösségi párbeszédnek sosem lesz elkötelezett híve. Ez a megfigyelés segíthet válaszolni arra a kérdésre, hogy miért csak néhány helyen, és miért ilyen lassan terjed a módszer Magyarországon.

A zuglói kapitány vallja: a jól kiépített kapcsolatrendszernek köszönhetően a helyi problémákkal a rendőrség azonnal meg tudja keresni az illetékes hatóságot, személyt. Ilyenkor úgy tűnik, hogy a rendőr segített megoldani a problémát, miközben ő csak információt közvetített. Ez mindenképpen hálás szerep, és ennek megfelelően a rendőrök szívesen is csinálják. Nem is kell hosszasan győzködni őket erről. Az ilyen módon

18 Lásd: www.zuglo.hu/elismertek-a-munkajukat-17/ (2019. 07. 01.) 
elért presztízsnek viszont egy valóban komoly (köz)biztonsági, bűnügyi probléma esetén felbecsülhetetlenül nagy hasznát vehetik a rendőrök. Munkájukat a bennük bízó lakosok információkkal vagy tevőlegesen is segítik, így hatékonyabb lehet a bünmegelőzés, a felderítés vagy a bűnüldözés, és az ügyfelek még elégedettebbek lesznek. Az erről beszélő kapitány nyilvánvalóan látja az összefüggést a jó kapcsolati rendszer kiépítése és a rendőrök elfogadottsága között. A megkérdezett kapitányok mindegyike az első pillanattól kezdve egyértelmúen ennek kiváló eszközeként tekintett a Police Caféra.

\section{A házigazda kapitányok szerepe a Cafékban}

A házigazda rendőrkapitányok elmondták, hogy kifejezetten jól érezték magukat a Cafékban. A képzések és az előkészítő munkák alapján egy percig sem voltak aggodalmaik. Egyikük azt mondta, nem volt mit veszíteni, egy ilyen civil-rendőr párbeszéden csak nyerni lehet. Másikuk szerint innovatív módszer lévén, a résztvevőknek nem volt összehasonlítási alapjuk, amihez képest éppen az adott Cafét jónak vagy rossznak tarthatják. Aki elfogadta a meghívást, kíváncsian jött, mert szeretett volna hozzájárulni a munkához, és ezt meg is tehette. A harmadik nyilatkozó szerint már a kezdetekkor látszott, hogy korszerú és hatékony a módszer, s bár minden kezdet nehéz szokott lenni, de hamar érezhető volt, hogy a körzeti megbízottak jól érzik magukat ebben a szerepben.

Egyik kapitány sem csak protokollból volt jelen mindegyik Caféban, hanem azért is, hogy a beosztott rendőrök a vezető személyes jelenléte által is érezzék a támogatását. Saját szerepüket sem alul, sem túl nem értékelték. A megnyitón pár mondat után nyugodtan, elégedetten és büszkén nézték, hogy a kollégáik milyen jól beleilleszkednek ebbe a szerepbe.

A képzésről úgy gondolják, nagyon alaposan felkészítette a kollégákat a szereplésre, így minden adott volt, hogy jól sikerüljenek a rendezvények. A szervezést is mindenhol értő kezekben tudhatták. A szervezők a meghívottak listáját természetesen a kapitányokkal is egyeztették. A „próbajáratok” során mindenki igyekezett biztosra menni, ami magas fokú felelősségérzetről tanúskodik, és meg is hozta a gyümölcsét.

\section{A házigazda kapitányok véleménye a munkatársaik Cafékban való szerepléséröl}

A kapitányok elmondták, hogy a rendőreiken jó volt látni a megfelelés vágyát, a szerepléssel járó egészséges izgalmat, a felkészültséget, azt, ahogyan komolyan vették a vendégeket, a témákat és önmagukat is. Mindez meglátszott a teljesítményükön, amit a vezetők mindannyiuknak meg is köszöntek. A zuglói kapitány büszkeségét fejezte ki, hogy a körzeti megbízottak a ZKNP jóvoltából a Café sorozat után külön jutalmat is kaptak.

A pécsi projektet a rendőrőrsök parancsnokai tartották a vállukon. A kapitány elmondta, hogy ez az ő személyes elhatározása volt, mert szerette volna, ha ezek a 40-60 ember munkáját irányító középvezetők ebben is példát tudnak mutatni 
a munkatársaiknak. Moderátorként magam, már az előkészítő egyeztetések alkalmával tapasztalva ezt az igényüket, nyilvánvalónak tartottam, hogy a döntés a kapitányok kompetenciája. Ennek oka, hogy elfogadtam: ők ismerik a helyi sajátosságokat és a kollégáikat, és tudják, kiktől várható a legjobb teljesítmény. Az interjúkat végighallgatva és elemezve azonban kissé másként látom. A magyar rendészetben uralkodó erősen katonai típusú hierarchia szinte kizárólag a vezető egyszemélyi döntését preferálja. Ez a „szokás” a három bemutatott és elemzett helyszínen éppenséggel „jól sült el”, de ez teljességgel véletlenszerú. Mi lett volna, ha a vezetők nem jól választják ki a közremúködő rendőröket, mert történetesen nem ismerik őket, és/vagy nem egyértelmű és az értékrendjükkel nem ennyire egyező a Police Café filozófiája? Éppen erre az eshetőségre számítva - tehát tulajdonképpen a vezető tévedéshez való jogát is fenntartva - az volna kívánatos, ha egy demokratikus múködésű szervezetben az ilyen projektekbe bevonható közremúködőknek már a kiválasztása is közös konszenzuson alapulna. És itt utalok vissza a tanulmány mottójául választott gondolatra.

Ehhez kapcsolódik, amiről mindhárom kapitány beszélt: hogy a parancsnokok és a járőrök, körzeti megbízottak egy-egy asztalnál egymással is partneri módon dolgozhattak, ami mindenképpen hozzájárult az egyébként köztük dominánsan múködő hierarchikus kommunikáció oldásához.

A pécsihez hasonlóan gondolkodott a kiskunhalasi kapitány is. Amikor kissé talán önkényesnek tűnően ő maga javasolta a képzésre és a témagazda szerepre a kollégáit, amögött egy elég határozott vezetői koncepció rajzolódott ki. Bács-Kiskun megyében a 2017-ben rendezett első három Caféban a rendészeti, a bűnügyi, a vizsgálati és a közlekedési osztályvezetők, a vidéki őrsparancsnokok és a bűnmegelőzési előadó vezették az asztalbeszélgetéseket. A kapitány úgy vélte, sokat fog segíteni nekik, hogy a civilekkel kötetlenebbül beszélgetve a megszokott hivatali szerepükből kissé kiléphetnek, és a sokszor csak iratokból ismert problémákhoz is közelebb kerülnek. Az így szerzett információk közvetlenül náluk mint vezetőknél csapódhatnak le, ami hasznos lehet a munkában is. Másrészről a kapitány vallja, hogy a motiválást a vezetőknél kell kezdeni, amit a vezetőképzésben tíz éve dolgozván, a legmesszebbmenőkig osztok. Harmadrészt pedig így a civilek a vezetőket is megismerhetik, mert egyébként ritkán kerülnek velük személyes kapcsolatba. Egyébként a kapitány véleménye szerint „a városban egyre nagyobb elismerésnek örvendenek a kapitányság osztályvezetői, amihez a Police Café alkalmak is hozzájárultak".

Ami a Police Caféban a kapitányok szerint a legjobb, az az, hogy minden rendőr közremüködő végre olyan rendőr lehetett, amilyen szeretne lenni: bürokrata helyett láthatóan a közösségért dolgozó szakember. „Azt megélni, hogy az előtt a közösség előtt nyilvánulhatok meg, akiért dolgozom, és hogy ők közvetlenül visszajelzik a véleményüket, nagyon fontos motiváló erővel bír.” Ilyenkor a „szolgálunk” nem üres szlogen, hanem valós, megélt élményeken alapuló érzés. Amikor a civilek konkrét, köztük ülő és velük beszélgető rendőrökön keresztül egy kis betekintést nyernek a „kulisszák mögé”, és látják, megértik a rendőrség munkáját, az növeli a bizalmukat. 
Mindegyik kapitány szerint fontos, hogy a témagazda szerepre kommunikatív, kreatív rendőröket válasszanak, de azt is vallják, hogy fokozatosan olyanokat is szerepbe kell helyezni, akiknek e téren gyakorlásra, fejlesztésre van szükségük. A kisebbnagyobb sikerélmények - és itt hangsúlyozták az élmény szót! - ugyanis növelik az önbizalmukat, ami nemcsak ezeken a fórumokon fontos, hanem a hétköznapi munkában is. Érdekes adalék egyébként, hogy a jelenlegi pécsi őrparancsnokok mindegyike 2004ben részt vett „A mi rendőrünk”-programban is, s az azóta eltelt tíz évben szakmai karrierjük egyértelműen felfelé ívelt. Évszámaikkal nemcsak tapasztalatuk, de végzettségük és a váll-lapjaikon lévő csillagok száma is gyarapodott, és ennek megfelelően hivatali beosztásuk is komolyabb lett.

Egy nagyon fontos vezetői attitűdre szeretném felhívni a figyelmet. A projekt elején mindhárom kapitány egyértelműen és nyíltan megfogalmazta a kollégái számára az elvárásait, ehhez megadta a tág kereteket, és onnantól kezdve teljes mértékben rájuk bízta a szervezést és a kivitelezést. Így a végrehajtás nem egy kötelező penzum teljesítését jelentette, hanem egy önálló, kreatív munkára lehetőséget adó kihívást. A szükségszerủ kezdeti izgalmakat nem számítva mindenhol jó hangulatban, egymást mindenben támogatva zajlottak a rendezvények, ezért a végén a kis csapatok elégedetten nyugtázhatták, hogy sikeres projektet zártak. Mint valamennyi helyszínen a rendőöket személyesen is ismerő moderátor, hozzáteszem: mindenhol eleve jó volt a kollégák egymáshoz való viszonya. Ez szinte már előre garantálta a program sikerességét. És - mindhárom kapitányt személyesen ismerve - azt is megkockáztatom: ezeknek az alapvetően jó emberi kapcsolatoknak az egyik fő generálója a vezető személye.

\section{A témagazda rendörök véleményei}

Négy rendőr témagazda volt a meginterjúvoltak között. Egyikük bűnmegelőzési előadó, másikuk őrsparancsnok, a harmadik körzeti megbízott, a negyedik pedig búnügyi osztályvezető-helyettes. Három tiszt és egy tiszthelyettes, aminek egyébként nem önmagában van jelentősége, hanem inkább az ebből fakadó beosztás okoz eltérő nézőpontot mindegyiküknél. A bűnmegelőzési szakember szemüvege szükségszerúen ez irányba elfogult. A vidéki nagyváros őrsparancsnoka középvezetőként más rendőrök - többek között körzeti megbízottak - irányítójaként is tekint a helyi problémákra. A bűnügyi osztályvezető-helyettes szintén középvezetői pozíciójából adódóan hivatali szemmel tekint a Caféban játszott szerepére. A körzeti megbízott viszont a napi történésekhez legközelebb lévén, talán a legautentikusabb, legsokrétűbb és legnaprakészebb tapasztalatokkal rendelkezik azokkal a problémákkal kapcsolatban, amelyek témaként az asztaloknál felmerültek. Négyük nézőpontjai igen jól kiegészítik egymást, s ezt a személyük kiválasztásakor is szem előtt tartottam.

Az egyik vidéki témagazda az adott városrész őrsparancsnoka volt. Sok, a programba bevont rendőrhöz hasonlóan ő sem volt kifejezetten lelkes az elején. Úgy fogalmazott, hogy amikor értesült erről a váratlan, új, számára ismeretlen feladatról, akkor 
„egy újabb púpnak” érezte a hátán. Hasonló kifejezéssel élt a körzeti megbízott témagazda is: „ez is egy újabb kolonc lesz a nyakamon”. Ez a hozzáállás a nyilatkozók szerint egyébként sajnos sokakra jellemző, és azzal magyarázzák, hogy a rendőrség sokszor olyasmit is magára vállal, ami nem az ő dolga lenne. Elmondták, hogy eleinte ezt a programot is ilyennek tartották, ám ahogyan elmélyedtek benne, változott a véleményük. Utólag egyértelmú lett a számukra, hogy ez a program a rendőrség valódi céljaihoz illeszkedik, és nemhogy nem egy újabb fölösleges feladat-végrehajtás, hanem nagyon is hasznos tevékenység.

A kezdeti idegenkedést magyarázta az őrsparancsnok 25 éves tapasztalatán alapuló állítása, miszerint az embereket a biztonsággal kapcsolatos problémákkal nagyon nehéz megszólítani, miközben a bajokat nagyon is érzékelik. De a hétköznapokban sem idő, sem alkalom nemigen látszik a megoldásukra. Inkább negligálják a problémát, elkerülik, elodázzák, másra hárítják a megoldás kötelességét. Csakhogy a rendőrség senkire nem mutogathat. „Gondoltam, majd ezen a feladaton is túlleszünk” - mondta a Caféról. Meglátása szerint ezzel az érzéssel nem volt egyedül. De hangsúlyozta, hogy egyfelől a moderálásnak, másfelől a résztvevőknek köszönhetően egy könnyedebb műfaj bontakozott ki a beszélgetések során. A kezdeti feszültségeket, az újtól való idegenkedést emelte ki, mert a rendőrök legtöbbje nem szokott a nyilvános szereplésnek ehhez a formájához. Úgy érzékelte, ahogy haladtak befelé a programba, a gátlások fokozatosan oldódtak, és végül mindenki jó érzéssel állapította meg, hogy nem egyszerűen teljesítették a feladatot, hanem belefeledkeztek a probléma felvetésének és boncolgatásának élményébe. Egyértelműen ezt az oldódást, az egymás iránti nyitást, közeledést látta a kollégáin és a civil vendégeken is. Ezt legjobban azon lehetett érezni, hogy mindig nehezen álltak fel egyik asztaltól és indultak el a másik felé. És a rendezvény végén is úgy kellett szinte kitessékelni a vendégeket. Az egyik fő különbséget más rendőr-civil fórumokhoz képest abban ragadta meg, hogy itt mindkét fél szerint valódi párbeszéd zajlott. Nem kiállt egy rendőr, és a hallgatóság kritizálta, amit mondott, hanem együtt gondolkodva keresték a megoldásokat. Ez egy nagyon jó fajtája a lakosok „manipulálásának”, mert valójában nem is manipuláció, hanem egy irányított, célorientált beszélgetés. A cél a problémák őszinte, mégsem sértő kimondása, az okok feltárása, majd ezek alapján a megoldások keresése.

A bűnmegelőzési szakember számára sem a program célja, sem maga az interaktív müfaj nem volt szokatlan. Várta az új módszert, amelyben annak lehetőségét látta, hogy újabb felületet kínál a rendőrség tevékenységének megismertetésére. Munkájából fakadóan hisz a nyilvánosság erejében, és igyekszik támaszkodni rá. Ő inkább a szervezéssel járó rengeteg munkát, izgalmat emelte ki, amely szükségszerűen neki jutott. Az érintettek elemzése, a meghívás, a helyszínek előkészítése egyszerre volt számára kihívás és kedves kötelesség. Előre sejtette, hogy hálás feladat lesz a civileket sajátos módon „vendégül látni”. Afféle kapcsolati befektetésnek fogta föl azt az energiát, amit ebbe a sorozatba - és ezt már én teszem hozzá - egyébként messze a kötelezőn felül beletett. 
Ő is arról a fordulatról számolt be, amely a beszélgetések során mind a kollégáknál, mind a civil résztvevőknél magától bekövetkezett. Legszebb élményeként azt említette, ahogyan fokozatosan mindenki bekapcsolódott a beszélgetésbe. Igazán abban látja a módszer „varázsát”, ahogy „behúzza” az embereket. A kisebb asztaltársaságok pont akkora nyilvánosságot adnak, amekkora előtt még az egyébként visszahúzódó emberek is szívesen elmondják a véleményüket. A rendőr témagazda moderálásának köszönhetően tíz perc alatt kialakul egy szimpátia, és annyira megerősödik a bizalom, hogy szívesen beszélnek. Nincs rossz vélemény, mindenkinek lehet hozzáfüznivalója, véleménye. Szerinte azonban ez a módszer a parancsuralmi múködésú rendőrségnél nagyon szokatlan volt. A rendőrök ezért még nehezebben oldódtak föl, mint a civilek, de végül mégis sikerült kilépniük a megszokott kommunikációs keretekből. Ez pedig felszabadítóan hatott a kreativitásukra, ami egyértelmúen segítette a civilek felé fordulást.

A témagazda szerepbe ki könnyebben, ki nehezebben tudta beleképzelni magát. A bűnmegelőzési szakembernek okozta a legkevesebb gondot, bár saját bevallása szerint érezte, hogy bizony „fogni kell a gyeplőt”. Mederben, irányban tartani 6-8 ember beszélgetését nem egyszerű feladat. Ráadásul a civilek előtt mégiscsak a rendőrséget képviselték, átérezvén ennek minden felelősségét, ami eleinte feszélyezettebbé tette őket. Ebben még a helyszínek is befolyással bírtak. Egy impozánsabb intézmény (mint amilyen Pécsett a Zsolnay Negyed, Kiskunhalason a Csipkemúzeum, vagy Zuglóban a Vajdahunyadvár) már önmagában a nagyobb, komolyabb elvárások képzetét keltik a vendéglátókban. És az is könnyítette vagy nehezítette a dolgát a témagazdáknak, hogy éppen saját körzetükben vannak, vagy besegítenek egy másikba. Megfigyelésük szerint nagyon meghatározó volt a vendégkör is. Ha illusztrisabbak voltak a meghívottak, az nyilván nehezítette a témagazda dolgát. De minden nappal egyre könnyebb lett. A legjobb élménynek azt tartják, amikor eljutottak a biztonság terén is meglévő közös nevezőkig. Ennek még a későbbiekben lesz jelentősége.

$\mathrm{Az}$ interjút adó házigazda körzeti megbízott keserűen mondta, hogy az embereket vagy közönyösnek látja, vagy agresszívnak. A lakossági találkozókon elbeszélnek egymás mellett, a civilek elmondják a sérelmeiket, a rendőrök pedig megpróbálnak védekezni és hárítani. De a Cafékban nem ez történt, itt valódi, őszinte beszélgetéseket tapasztalt meg.

Egy másik témagazda azt emelte ki, hogy a módszer a civilekre leginkább az újdonság erejével hatott, hiszen ami új, az általában jó. Saját maga számára pedig ezt a szerepkört kifejezetten komfortosnak tartotta. Vagyis már az hasznos volt, hogy az ember azt csinálhatja, amit szeret.

Ez a szerep a rendőrök számára is más. Itt a résztvevőknek nem volt okuk elferdíteni a tényeket vagy elzárkózniuk, tiszteletlennek vagy ellenszenvesnek lenniük. Nem jöttek be a tipikusan kötekedő kérdések sem. Kérdeztek, de lényeges, tartalmas, érdemi dolgokat. Ez a fajta találkozás mindenkinek az együttműködő arcát segít kidomborítani. Itt egyszerúen nem lehet nem hozzájárulni. Ez a természetes hangulatú beszélgetés megoldja az emberek nyelvét. De a témagazdák mindenképpen úgy érzik, hogy mindehhez kell a moderátor, aki mederben tartja a témát, a témagazdákat és a vendégeket is. 
Szinte mindenkinek könnyebben ment az egész, mint ahogyan előre gondolta. A nyilatkozó rendőr témagazdák jól érezték magukat ebben a helyzetben, és úgy vélik, társaik döntő többségének is testhez álló volt ez a szerep.

A témagazdák az asztaloknál átbeszélendő témák jó megválasztását kulcsfontosságúnak tartják, és szerintük mindenhol sikerült eltalálni, mi érdekli leginkább a közvéleményt. Egyik-másik téma egyáltalán nem bizonyult könnyúnek, mégsem érezte senki, hogy „belesültek” volna bármelyikbe. Egy-egy, már a sorozatok után rendezett önálló Caféban, amikor már csak egy konkrét helyi problémát vetettek föl, még arra is ügyeltek, hogy kellően diszkréten nyúljanak a témához. Ezt például tapasztalatuk szerint azzal lehet elérni, hogy nem az adott ügy konkrétumairól, hanem a probléma általánosabb aspektusairól beszélgetnek. Ez a problémákhoz való viszonyulásnak már igen magas foka, és a kollégák szociális kompetenciáinak meglétét jelzi. Az a kolléga, aki erről beszámolt, rendőri munkája előtt egy olyan területen dolgozott, ahol a diszkréció szintén alapkövetelmény volt. Így lehet, hogy számára ez azért magától értetődő.

A témagazdák szerint a Café módszer nagyon jól használható személyes szinten a kommunikációs készségek fejlesztésére, a szereplés, a nyilvánosság előtti beszéd, a másik emberre való odafigyelés gyakorlására is. Ugyanezt látták a rendőrök egymáson is. Nem rendőri szemmel nézni, figyelni a másikat, hanem odafigyelni rá üdítő volt részükre. A jegyzetelést és az összefoglaló prezentáció elkészítését, előadását is inkább élvezték, bár ezt azért nem tartották könnyű feladatnak.

Egyikük a saját fejlődését így fogalmazta meg: „Bővült a repertoárom, azáltal, hogy olyan emberek szakmai tevékenységére is rálátásom nyílt, akikére korábban egyáltalán nem.” És viszont: „A rendőri munkába is betekintést nyertek a civilek, ami mindkét félnek jót tett." A közeledés egyik legbeszédesebb jeleként az egyik témagazda rendőr egy résztvevő kezdeti magázódásának tegeződésre váltását emelte ki.

Van azonban olyan témagazda, aki szerint az emberek egyáltalán nem kíváncsiak a rendőrök emberi arcára, és ezen a téren a Café alkalmak sem hoztak közeledést a két fél között. Számára bizonyára meglepő lesz a civilek erre vonatkozóan kifejtett ellentétes véleménye. Ugyanennek a kollégának a kivételével a rendőr interjúalanyok azt is kiemelték, hogy mennyit változott mind a saját, mind a civilek fogalmi rendszere a biztonsággal és a renddel kapcsolatban. A továbbiakban erre is kitérek még.

A rendőrök fontosnak tartják, hogy a hatósági szerep helyett egy másik, az emberi oldalukat mutathatták meg, és ezúttal erre is kíváncsiak voltak a civilek. Biztosak abban, hogy ez az egész rendőrség megítélésének is jót tesz. Az egyik témagazda nehezményezte, hogy a magasabb vezetők nem támogatják jobban (vagyis egyáltalán) ezt a programot, és csak annak a néhány szakembernek az „élvezeti szereként” kezelik, akik részt vettek benne. Ahhoz, hogy ugyanilyen színvonalon lehessen folytatni a Cafékat, nagyon kellene a professzionális szervezés. És erre hiába van igénye mind a civileknek, mind a rendőröknek, valami mégis hiányzik ahhoz, hogy több helyen legyen ilyen rendezvény, vagy ahol már volt, ott megismételhessék igény szerint. A körzeti megbízott munkájának ugyanis a lakossággal való rendszeres és valódi kapcsolattartás a lényege, és talán a bűnmegelőzés számára is sok kiaknázatlan lehetőséget rejtenek az efféle találkozások. 


\section{Reflexiók a képzésekre}

\section{A képzés elökészitése és a módszertani felkészitö képzések}

„A képzésre kétkedve ültem be, de ahogy ott felvezetted a programot, ahogy lelkesítettél bennünket, az kezdte felkelteni a kíváncsiságomat” - talán ez a legjellemzőbb azoknak a rendőröknek a hozzáállására, akiket végül is kisebb-nagyobb vezetői preszszió „kényszerített” be a Police Café módszertani felkészítő képzésekre.

Rendkívül tanulságos volt az egyik bűnügyes identitású - és ez fontos! - témagazdának az interjú során adott visszajelzése a képzést előkészítő találkozásról: „Az első tájékoztató nekem egy kicsit sejtelmes volt, nem értettem, miért így vezetted föl a módszert. Jó lett volna látnom egy összképet az egészről. Ez talán azért van, mert kissé türelmetlen alkat vagyok, vagy mert rendőr vagyok. A hétköznapokban egy bünügyben is információmorzsákból próbálom összeállítani a teljes képet, de az mégis más. Jelen esetben tudtam, hogy te mint moderátor a teljes információ birtokában vagy, ezért nem értettem, hogy akkor miért nem a lényegnél kezded. A végén persze összeállt a kép, de nekem ez jobban jött volna már az elején. Azt javaslom, hogy az első tájékoztatást mindig azoknak a szakembereknek a habitusára szabd, akikkel éppen beszélsz.” Külön érdekesség, hogy aki ezt a véleményt megfogalmazta, betegség miatt magáról a képzésről lemaradt, így kvázi „kiképzetlen” témagazdaként ugrott be a szerepbe. Persze azért mielőtt erre sor került, egy másik Caféban egy felkészült témagazda mellett segédkezett. És végül nemcsak hogy helytállt, de saját elmondása szerint élvezte ezt a fajta beszélgetést a civilekkel.

\section{Add tovább!}

Már 2014-ben az első Police Café sorozatnak sem indultunk neki anélkül, hogy a leendő témagazdák ne kapjanak felkészítő képzést. Azóta is ragaszkodom ehhez, mert csak így garantálható az eredeti módszertan maradéktalan betartása. 2014. május 12-én Pécsett egy egész napot töltöttünk el azzal, hogy a leendő rendőr témagazdák kipróbálják, milyen is ez a forgószínpadszerű párbeszéd, és hogy átvegyük a szervezéshez szükséges tudnivalókat. Ezt követően 2014 júniusában 4 egymást követő napon 4 Cafét rendeztünk, a visszhangok szerint egyértelműen nagy sikerrel. 2015. május 12-én, napra pontosan egy évvel az első képzés után, a pécsi rendőrök a VIII. kerületi szomszédsági járőröket látták vendégül, ${ }^{19}$ hogy egy egynapos tapasztalati képzésen megtanítsák nekik a módszertant. Erre egy akkor záródó józsefvárosi szomszédsági rendőr projekt utolsó epizódjaként került sor. A vendégek kipróbálhatták, hogy néz ki a gyakorlatban a Café módszerú párbeszéd.

A meginterjúvolt pécsi rendőrök ebben a képzésben a legérdekesebbnek azt tartották, ahogyan összetalálkozott a vidéki nagyvárosi és a budapesti rendőri szubkultúra.

19 Lásd: http://policecafe.hu/police-cafe-pecs-budapest-2-1/ (2019. 07. 01.) 
A két nagyjából hasonló méretủ kapitányságon ugyanis egészen más emberi viszonyok múködnek. A vidéki állandóság, a személy- és helyismeret, az egymásba vetett bizalom a vezetőkkel való közvetlen viszonyra is jótékony hatással van. A pécsieknek jót tett, hogy ezt egy külső tükörben is megláthatták. Egy pécsi interjúalany azt is megfogalmazta: „Jó érzés volt, hogy mi egy picit előrébb vagyunk, és mi mutathatunk nekik valami újdonságot." De ezt egyáltalán nem a versengés mondatta vele, hanem inkább az afölött érzett öröm, hogy a tapasztalatot, tudást át lehet adni a kollégáknak. Eddigre Pécsett már kezdeti eredmények is akadtak, de a kétségeiket sem hallgatták el a kollégák. Nem „kirakatrendezés” zajlott, hanem egy őszinte, kritikai, elemző, reflektív párbeszéd. Ami még feldobta ezt az alkalmat, az az, hogy a pécsi sorozat óta már egy év telt el, és a helyieknek éppen ideje volt visszatekinteniük az akkori folyamatokra. Így a leülepedett élmények strukturálva, átgondolva, mélyebbről kerültek elő. A pécsiek fontosnak érezték, hogy sikerült megtalálni a közös hangot a budapestiekkel, hisz ahogy mondták: „mégiscsak mindannyian rendőrök vagyunk”.

\section{Szupervíziók}

Pécsett közvetlenül a négynapos sorozat után volt egy félnapos reflexió, ami még frissiben érte a szakembereket. Az értékelés és összefoglalás minden közremüködő jelenlétével, teljes mértékben partneri hangnemben zajlott. A helyi vezetők is magától értetődőnek tartották, hogy valamennyi résztvevő értékeli a projektet. Mint láttuk, az egy évvel későbbi képzés, ahol a VIII. kerületi rendőröknek adtuk át a módszertant, már egy kiérleltebb visszatekintésre adott alkalmat. Bár nem tudatosan terveztük így, de mindkettőt tekinthetjük egyfajta szupervíziónak.

A 2017-es nagyobb Police Café sorozatok lezárultával Bács-Kiskun megyében és Zuglóban is összegeztük a szakmai tanulságokat, de ezt már tudatosan beterveztük a pályázati támogatásban is részesülő projektekbe. Zuglóban szupervízióként egy egész, Bács-Kiskunban egy fél napot töltöttünk együtt a közreműködő rendőrökkel, és természetesen Café módszertannal dolgoztunk. ${ }^{20}$ Mindkét helyen a szervezők és a moderátor mellett a helyi rendőrvezetők is vállaltak témagazda szerepet, ami nagyon jót tett a beosztott rendőröknek.

\section{A Police Cafék meghívott civil vendégeinek véleményei}

\section{A meghívásról, a részvételröl, saját szerepükröl}

Arra a kérdésre, hogy mit szóltak a meghíváshoz, valamennyi meginterjúvolt civil egyértelműen azt felelte, hogy örömmel fogadták, és megtisztelőnek tartják, hogy az intézményük részt vehetett a programban. Ami a legnagyobb újdonság volt számukra,

\footnotetext{
20 A zuglói és a Bács megyei szupervíziókról lásd részletesen itt: http://policecafe.hu/michelangelo-es-a-rendorok-police-cafe-zarorak/ (2019. 07. 01.)
} 
hogy a jogalkalmazók megkérdezték a civileket arról, mit gondolnak saját és környezetük biztonságáról, és hogy ebben a tanácsaikat, ötleteiket is kikérték.

Mindegyikük pontosan értette, miért kapott meghívást. Az egyik ok, hogy mint a biztonsággal közelebbi vagy távolabbi kapcsolatban lévő szakemberek, intézményvezetők, döntéshozók nem elsősorban a saját, hanem a mások biztonságáért is felelősek. Az egyik interjúalany több mint tíz évig volt egy egészségügyi intézmény igazgatója, ahol az ellátott betegek száma évi 500 ezer fő. Az ezzel járó forgalom már önmagában sok biztonsági veszélyt rejt magában. Két dolgot emelt ki ezek közül: az egyik a bent fekvő betegek vagyonbiztonsága (annak idején ők is 500 széfet vásároltak, de ez nem hozott megoldást), a másik a személybiztonság. Az utóbbi növelésének érdekében egy biztonsági szolgálattal kötöttek szerződést, de mindössze egyetlen őr dolgozott, és ő sem volt hatékony: az udvarról kerékpárokat loptak, autókat törtek fel. Erre eleinte a kamerarendszer látszott megoldásnak, de jogilag ez is nehézségekbe ütközött. Vallja, hogy a rendőrséggel való együttmúködés és a megelőzési szemlélet elterjesztése hatásosabb lehetne.

A sajtó képviselője a napi hírgyártás során sok lakossági panasszal találkozik, amelyek kezelésében, feldolgozásában napi kapcsolatban kell lenniük a helyi rendőrséggel. A műsoraik fontos faladata a lakossági tájékoztatás, amelynek érdekében a helyi bünmegelőzési szakemberekkel nagyon jó kapcsolatot ápolnak. Ezért is örömmel tett eleget a meghívásnak.

A civil szervezet vezetője mondta ki, de mindenkire igaz, hogy minden ilyen alkalmat kapcsolatépítésre használ, amire a pozíciójából fakadóan nagy szüksége van. Esetükben különösen fontos, hogy ahol csak lehet, megmutassák magukat, hiszen sokszor érzi, hogy mint civil szervezetet a hatóságok nem veszik őket eléggé komolyan. Ez az értékpreferencia nagyon sértő, igazságtalan és szakmaiatlan is. Szerinte sokat jelentene, ha a mások munkájának valós értékét kölcsönösen látnánk és elismernénk, és erre is jó lehetne több ilyen szakmaközi Café. Jó volt számára olyanokat is látni megnyilvánulni, akiket korábban nem ismert, és hasznos volt kicsit „szemüveget cserélni” egymással.

\section{A módszerröl}

Magát a módszert a meginterjúvolt civilek egyike sem ismerte, de kíváncsiak voltak rá. A rendőrökhöz hasonlóan ők is zsákutcának tartják a „hagyományos” lakossági fórumokat. Még az önkormányzati képviselő is - nagy empátiával - egyenesen „kínzókamrának" nevezte ezeket, ahol a kapitánynak vagy a helyi rendőrvezetőnek a lakosság kínos, nem ritkán provokatív hangnemben feltett kérdéseire kell azonnal, lehetőleg megnyugtató válaszokat adni. Ilyen körülmények között szinte kódolva van a kudarc.

A polgárőr szövetség vezetője egy plázában korábban tartott Police Coffee ${ }^{21}$ rendezvényen már részt vett. Amikor először hallotta a Police Cafét emlegetni, azt hitte, ez is olyan

21 Lásd: http://jozsefvaros.hu/hir/1510/jozsefvarosban_indult_el_a_police_cofee/ (2019. 07. 01.) 
lesz, de hamar kiderült, hogy ez más. A fő különbséget a kétféle fórum között az alábbiakban látta. A plázában nem biztos, hogy az emberek maguktól odamennek a rendőrhöz kávézni, vagy ha igen, akkor is legfeljebb csak a saját problémájukkal, és néhány percre. A helyszínnek megfelelően csak ad hoc jelleggel és egyetlen témáról folyik a beszélgetés két ember között, felületesen. A Police Caféban viszont előre megtervezetten, 16-20 meghívott körében, moderáltan, egyszerre több témában, a végén összegzéssel zajlik a beszélgetés, ráadásul az adott közösséget, egy-egy társadalmi csoportot, réteget érintő problémákkal foglalkoznak. A Police Café műfaja szokatlan, formabontó, egyáltalán nem merev, hivatalos, a beszélgetés inkább kötetlen. A vendégek nem magánemberként vannak jelen, hanem valamilyen intézményt képviselve. És üdítően hat, hogy senki nem ráerőszakolni akar a vendégekre valamit, hanem beszélgetésre invitálja őket, amit alapvetően szeretnek. Ugyanakkor az embereket megmozdítani és összehívni a legnehezebb, de ha ez sikerül, akkor ezzel a módszerrel jól lehet terelgetni a témát.

Egy pécsi nyilatkozó örül, hogy mind a négy városrészben megrendeztük a Cafét. Egy rendezvény nemcsak hogy túl nagy lett volna, de a kimaradt városrészek irigyelték volna a rendezőt. Így viszont lehetséges volt a differenciálás, és mindenhol a helyi ügyekről lehetett beszélgetni.

Az interjúalanyok közül ketten is szívesen megtanulnák a módszert. Egyikük a végzettségéből adódóan a változásmenedzsment és a szervezés iránt érdeklődve, illetve vezetőként is az emberek párbeszédét szorgalmazva, szakmai szemmel is figyelte a dinamikát. Szívesen látná a saját kollégáit hasonló szerepben, és örülne egy olyan készségfejlesztésnek, amelynek a segítségével ilyen hatékonyan tudnának irányítani szakmai beszélgetéseket. A szociális munkás képzésben sem látott ennél hatékonyabb csoportvezetési technikát, pedig ezt sok más területen is lehetne alkalmazni.

Már a téma felvezetése, a színes képek alapján zajló bemutatkozás közben oldódik az a feszültség, ami minden összejövetel elején jellemző. De igazán az első asztalbeszélgetésnél lehetett érezni, hogy mindenki „megérkezett”. Az egyik interjúalany biztos volt abban, hogy az asztaltársaságok összeültetése bizonyos koncepció mentén történt, ami szerinte nagyon jó, mert így olyanok is beszélgettek egymással, akik egyébként maguktól talán egy asztalhoz sem ülnének. Márpedig egy-egy ügy nagyon is igényli, hogy az adott szervezeteket képviselő szakemberek végre elkezdjenek együttmúködni. Ehhez pedig bizony szóba kell állniuk egymással.

A civilek szerint a rendőr témagazdák hamar átsegítették a résztvevőket a konstruktív párbeszédbe, és ehhez nagyon alkalmas az a puzzle-technika, amellyel egy nagy témát kisebb résztémákra szedünk szét, majd a végén ezeket összeillesztjük. A módszer legfontosabb részének az összegzést tartják: az egyes asztaltémák összekapcsolódnak, összeadódnak, és az üzenetek érezhetően „megérkeznek” minden résztvevőnek. A megértés kíváncsiságot vált ki, bevonja őket, és nemcsak a problémák felvetésére, kimondására, de a megoldások keresésére is ösztönöz. Azt is érzékelték, hogy a megoldásokhoz a szakemberek már ott helyben össze tudnak kapcsolódni, egyezséget kötni, elköteleződni. A televíziós szerkesztő kifejezetten úgy gondolja, hogy a helyi rendőrök 
a Police Café résztvevőinek véleményét, hozzászólásait figyelembe véve alakítják a lakosság tájékoztatását a bűnmegelőzés érdekében.

Különösen hasznosnak tartják, hogy olyan összefüggésekre derül fény, amelyeket korábban nem tudtak. És olyan problémákat, amelyeket korábban rendészeti kérdésként kezeltek, holott egyáltalán nem azok, kvázi vissza lehet adni a problémát valóban kezelni tudó szervezeteknek, intézményeknek. A rendészet sokszor ugyanis legfeljebb a problémák tüneteit tudja kezelni, azt is csak felszínesen, ideig-óráig, de a valódi okokat csak másokkal együtt lehet megszüntetni, persze ha ezt felismerik, és van rá szándék is. Ezt a programot erre nagyon alkalmasnak tartják.

\section{A rendörségröl és a rendörökröl}

A rendőrök esetében láthattuk, hogy szerintük a civileknek a rendőrségről, a rendőrökrôl alkotott véleményére is jó hatással voltak a Cafék. Nézzük, miként beszéltek erről a civilek.

Már azt példaértékűnek és motiválónak tartják, hogy a rendőrség állt elő ezzel az innovatív lépéssel. Hiába dolgoztak együtt velük korábban sokféle módszerrel más rendőrségi, elsősorban bűnmegelőzési programokban, még soha nem sikerült betölteni azt az űrt, amit most igen. A rendőrök egészen más szerepben mutathatták meg magukat, képletesen szólva: „kinn maradt a bilincs és a gumibot”.

„Ritkán van alkalmam rendőrökkel beszélgetni, de ez a mostani két alkalom a velük szemben meglévő szokásos sztereotípiáimat segített oldani. Megismerhettem az emberi oldalukat. És egy fontos történeti adalék: nem lehet nem észrevenni, hogy a legelső, 2010. áprilisi, még egyedi kezdeményezésű, tulajdonképpen amatőr körzeti megbízotti plakáthoz képest a mostani »Szomszédom a rendőr!« arculatig mennyi fejlődésen mentek keresztül a kerületi rendőrök. A témagazda szerep kihozta a személyiségük jellemzőit, és mindenkivel jó élményem volt, ügyesen vezették a beszélgetéseket. Dolgoztam más kerületben, ahol vagy más típusú kapcsolódásom volt a rendőrökkel (egy Kábítószerügyi Egyeztető Fórum tagja voltam, és ott egy rendőrrel együtt szerveztünk a kapitányságon képzést a kollégáinak), vagy semmilyen. De ott nem is volt ilyen típusú kezdeményezés, csak a szokásosan bürokratikus és fentről vezérelt, merev rendszer müködött. Azaz éppen hogy nem müködött: csak akkor mozdult bármi is, ha az a rendőrség érdekében is állt. Ez tehát egy nagyon új rendőrkép volt számomra, és nagyon szimpatikus."

Ugyanezen interjúalany szerint egy jól megalapozott szakmai kapcsolat egy-egy konkrét ügy vagy rendezvény kapcsán sokat jelentene a megfelelő segítség megtalálásában. Ha az általa vezetett civil szervezetnek több rendőrrel lenne szorosabb a kapcsolata, az azért is jó lenne, mert szerinte a rendőrök több droghasználó fiatalt érnek el, és ha ismernék a segítő szervezetek munkáját, akkor többeket tudnának hozzájuk irányítani. 
A szervezést is kitűnőnek vélik a civil válaszadók, és kiemelték a kapitányok pozitív, motiváló, elkötelezett hozzáállását is. Korábban ilyen minőségben nem mindegyikük találkozott rendőrökkel, de a kiskunhalasi interjúalanyok elmondták, hogy más nyilvános fórumokról is csak jó tapasztalataik vannak a rendőreikről. Az egyik intézményvezető külön kiemelte, hogy az előző kapitány miatt a rendőrséggel nem volt éppen zökkenőmentes az együttmúködésük, de az új kapitány megjelenésével ez azonnal és gyökeresen megváltozott. Ez mindenképpen pozitív üzenet egy kerületi kapitányságról. Egy másik válaszadó szerint is alapvetően a kapitányokon múlik, hogy vannak-e ilyen programok. Sajnos ez látszik akkor is, amikor egy vezető távozik egy pozícióból, és vele együtt múlik ki egy korábban sikeres kezdeményezés, és nem ritkán sérül vagy megszűnik az együttmüködés is. A Café módszer meghonosodása ezt a problémát is segíthet áthidalni: ha sok szakember megtanulja, és a közösségi párbeszéd úgymond „önjáró” lesz, már nem a vezetőtől fog függni - azaz nem az ő „engedélye” kell -, hogy ilyen módon dolgoznak-e együtt a közösség tagjai.

A szociális szakembernek pozitív csalódás volt az a professzionalitás, amellyel a rendőrök felépítették az egész folyamatot. Egyetlen rendőrön sem látszott, hogy nincs a helyzet magaslatán. Nagyon díjazta, hogy annak ellenére kiválóan megoldották a feladatot, hogy tudja: csak 8 órás módszertani képzést kaptak. A témagazda rendőökre nyugodtan rábízták magukat, mert felkészültek, tájékozottak, hitelesek, meggyőzőek voltak. A nagybani jegyzetelés is nagyon sokat segített a gondolatok összerendezésében, strukturálásában, láthatóvá tételében. A témagazda rendőrökkel többen ismerték egymást, ami már önmagában megalapozta a bizalmat. Az egyik vezető így nyilatkozott: „Amikor a város »krémje« ott ült, azt lehetett érezni, hogy valamilyen szinten egymásnak is meg akarunk felelni. A témagazda nagyon jól moderálta az esetlegesen adódó kisebb nézeteltéréseket, vitákat is. Ilyesmire adhatott volna okot például az a tény, hogy 2016-ban, az első Café idején Kiskunhalason a menekültkérdés igencsak napirenden volt. De szerencsére ez a téma nem hogy nem lett uralkodó, de jóformán föl sem merült."

Szinte az összes zuglói Caféban jelen lévén, a szociális szakembernek jó összehasonlítási lehetősége adódott. Azt tapasztalta, hogy miközben ugyanazt a nagy zuglói biztonsági puzzle-t rakosgatták, mégis mindenhol más és más képet kaptak. Az egyes körzeteknek ugyanis természetesen megvannak a saját tipikus problémái. A témagazdák, akik a körzetekben „otthon vannak”, képesek voltak meglátni a helyi vendégek igényeit, és az egyes témákat arra vinni, amerre az aktuális asztaltársaságok akarták. Persze a beszélgetések elején megvolt az alapkoncepciójuk, mégis rugalmasak és alkalmazkodók voltak.

Mindannyian azt érzik, hogy az asztaloknál ülő rendőrökkel is sokkal mindennapibb lett a kapcsolatuk. Ez azt jelenti, hogy célzottabb, rendszeresebb, közvetlenebb a viszonyuk, a közös megoldásokat gyorsabban megtalálják, lerövidülnek az addig csak hatósági, tehát közvetett, hosszadalmas utak. Másrészt sokkal emberközelibbé váltak maguk a rendőrök is: „Immár Lacit és Karcsit hívjuk, és nem »a« rendőrséget.” 


\section{A Police Cafék szakmai hozadéka}

Joggal merül fel a kérdés, hogy a vizsgált időszak Police Café sorozatainak lezárultával kimutatható-e valamilyen hatás az adott területeken. Vajon tovább él-e a program, és ha igen hogyan? Az alábbi fejezetben erre keresem a választ, és közben felvázolom a biztonság fogalmának egy olyan újszerú megközelítését is, amely a rendőrképzésben szerzett több mint húszéves tapasztalatom, a négy és fél éve zajló Café fórumok, illetve az interjúalanyokkal folytatott értékes, mély, elemző szakmai beszélgetések alapján érlelödött meg bennem.

\section{A rendörök véleményei a Police Cafék utóhatásairól}

A zuglói kapitány elmondta, hogy szerette volna, ha 2018-ban minden körzetben a helyi rendőrök megtartanák a saját kisebb Police Caféjukat. De nem kötelező jelleggel, inkább úgy fogalmazott: örülne neki. Pozitív motiváló eszközt is tett az elvárása mögé: „A körzeti megbízottak jutalmazási rendszere úgy van kialakítva, hogy a Police Café megtartása egy objektív feltétele annak, hogy valaki részesüljön jutalomban." Két ilyen rendezvény, a 2018. június 4-én a Rákosszeg Café és 2019. április 5-én a Roma-Police Café - bár meggyőződésem szerint egyáltalán nem e külső motiváció miatt - már meg is valósult. ${ }^{22} \mathrm{~A}$ kapitány szerint az ezekben a Cafékban elért kisebb, ám már konkrét eredmények számítanak ,igazán szakmai sikernek”. Ebből a beszélgetésből vált világossá számomra, hogy rendőrök és civilek mennyire mást értenek sikeren, eredményen.

A rendőrök - és ebben nem sok különbség látszik sem a nyilatkozó vezetők és beosztottak, sem pedig az egyes szakterületeket képviselők között - egyértelmúen azt tekintik eredménynek, amikor valamilyen (köz)biztonsággal kapcsolatos konkrét problémára valami „kézzel fogható” megoldás születik, és ennek híre is megy. Akár abban az értelemben is, hogy a felsőbb vezetés vagy más kapitányságok is elismerik a sikereket. Mivel a Police Café által lehetôvé tett párbeszéd megelőzés-központú, a rendészeti szakmát képviselők klasszikus aggálya vetődik fel vele kapcsolatban: hogy ugyanis nem lehet megmondani, mennyi bűncselekményt sikerül megelőzni ilyen módon. Látható, hogy még a legmodernebbül gondolkozó, megelőzési szemlélettel bíró rendőrvezetőknek is nehézséget okoz, hogy belássák és elfogadják az efféle módszerek és programok egyértelműen pozitív hatását, amely nem a megelözött büncselekmények valóban kimutathatatlan számában, hanem a közösségmegtartó erejének növelésében rejlik. Véleményem szerint ez a nézet azért uralkodó, mert ők is többnyire arra szocializálódtak, hogy a hagyományoknak megfelelően rendőrként legfóképpen a bủncselekmények hiányában mérjék a (köz)biztonságot, miközben - és ezt mindjárt látjuk -, a civilek megközelítésében a biztonság nagyrészt mást jelent.

\footnotetext{
22 A részletes leírást lásd itt: http://policecafe.hu/zuglo-folytatja-a-masodik-police-cafe-kepeslapom/ (2019. 07. 01.); http://policecafe.hu/police-cafe-extra-14-ketnyelvu-parbeszed-a-meg-biztonsagosabb-zugloert/ (2019. 07. 01.)
} 
Bizonyos értelemben a civilek is „kézzel fogható” eredményeket várnak, csakhogy ők beérik más jellegú, kisebb, nem szoros értelemben vett (köz)biztonsági problémák, hanem a terület élhetőségét befolyásoló ügyek érezhető, jól látható megoldásával is, amilyen például egy utca tisztasága, egy út járhatósága, egy parkolóhely kialakítása, egy zebra felfestése, egy jól megvilágított kereszteződés stb. Mintha ők jobban értenék, hogy ezek az „apróságok” is mennyire hatással vannak a biztonságukra. Amíg a két álláspont, a rendőröké és a civileké, nem közeledik egymáshoz, megmarad a feloldhatatlannak tûnő ellentét, amely örökös elégedetlenséget generál a helyi (köz)biztonsággal.

\section{A civil interjúalanyok véleményei a Police Cafék utóhatásairól}

A zuglói válaszolók szerint azért volt jó a sorozat, mert így a program lefedte az egész kerületet. A Caféban egyszerre voltak jelen a hatóság tagjai, a civilek, az intézmények, a segítő szervezetek képviselői, a szolgáltatók, a döntéshozók és a végrehajtók, és nem utolsósorban a lakosok. Szinte mindegyikük zuglói lakos vagy ott dolgozó volt, akinek valamilyen mértékben érdekében áll a helyi biztonság létrehozásához, fenntartásához való hozzájárulás. Némelyikük azonnal látta, hogy a jelzőrendszer megmozgatása, fejlesztése az egyik fő célkitǔzése a szervezőknek. A részvétel már önmagában jelképes értékű volt, hiszen itt mindenki konkrét ügyeket és másokat is képviselt. Az egyik résztvevő például így fogalmazott: „Akikkel egy asztaltársaságban ültünk, azokkal lett egy közös élményünk, és ez már önmagában is nagyon sokat jelent.” De igazán a résztvevők közötti párbeszédből lehet összerakosgatni azokat a puzzle-darabkákat, amelyek ki fogják adni a megoldásokat.

Annak a véleményüknek is hangot adtak a válaszolók, hogy miközben egy-egy ilyen beszélgetés jó élmény, és a résztvevők sok hasznosat megtudnak és kapcsolatokat gyüjtenek, az esetek nagy százalékában még sincs folytatás. Ennek okát persze nem a módszerben látják, hanem az emberekben. De arra, hogy felrázzon, megmozgasson egy kerületet, körzetet, várost, szerintük kiváló eszköz a Café, főleg ebben a sorozatos formában.

Különösen jó volt a közvéleményt jelentősen formálni, befolyásolni képes sajtót képviselő újságíró interjúalanytól hallani az alábbi mondatot: „Bízom benne, hogy ez a projekt igazi szemléletváltást hoz majd.” Hogy a reményeiről nemcsak a vele készült interjúban beszél, hanem sokat tesz is az ügyért, azt az a tény is bizonyítja, hogy a Halas Televízió - hiszen ennek a médiumnak a szerkesztőjéről van szó - híradós tudósításban és egy félórás, fő műsoridőben folyó stúdióbeszélgetésben is igényesen és értőn adott hírt a 2016-os kiskunhalasi Caféról, és azóta is rendre tudósít az ilyen eseményekről. ${ }^{23}$

\footnotetext{
23 A Halas Televízió műsorát és más Police Café rendezvények médiában való megjelenéseinek listáját lásd itt: http:// policecafe.hu/media/ (2019. 07. 01.)
} 


\section{Tisztázandó fogalmak}

Ezen a ponton érdemes kissé részletesebben elgondolkodni a (köz)biztonsággal kapcsolatos fogalmakon. Talán feltünik az olvasónak, hogy bizonyos összefüggésben - tudniillik amikor a rendőrök szempontjából emlegetem a biztonságot - zárójelben eléje teszem a köz- előtagot. Szándékosan kívánom ezzel is érzékeltetni, hogy ez rendôri szakkifejezés, amely mára teljesen átkerült a köznapi szóhasználatba is.

A rendőrök hajlamosak azt hinni, hogy ez a szó a civileknek is azt jelenti, amit nekik. Pedig nem, és ez a Police Cafékban is világosan kiderült. Volt olyan témagazda, aki kifejezetten azt a kérdést vetette fel az egyik Caféban, hogy mit értenek biztonságon a civil meghívottak. Most az interjúban is szívesen idézte fel, hogy ő maga lepődött meg legjobban, amikor összefoglaló prezentációjában értette meg: a civilek számára a biztonság nem egyszerúen a bűncselekmények hiányával egyenlő. Emlékszik rá, hogy a biztonsággal közeli értelemben használták az alábbi fogalmakat: együttmúködés, odafigyelés, bizalom, kiszámíthatóság, következetesség, hit, aktivitás, segítség, szolidaritás, információ, átláthatóság, tájékozottság, tájékoztatás, tisztaság, rend, nyugalom, közösség.

A Cafék moderátoraként erről a „felfedezésről” nekem is élénk emlékem van. És azt is tudom, miként beszéltek a Cafék előtti képzésen, majd a Cafékon az azokon részt vevő rendőrök a közrendről, közbiztonságról. Az interjúk során azt is volt alkalmam megfigyelni, hogy a kapitányok és a témagazda rendőrök által képviselt nézetek menynyit változtak, finomodtak. Határozott véleményem, hogy a civilekkel zajló Café beszélgetések hatására a biztonságról alkotott nézeteik kezdenek elszakadni a hagyományos közrendfogalomtól, és egyre inkább közelítenek a civilek elképzeléseihez. Mintha lassan, fokozatosan elkezdenének végre közös nyelvet beszélni. Egy 2018-as felmérés a hévízi rendôrőrs lefedettségébe tartozó néhány önkormányzat vezetőivel ugyanerre a következtetésre jutott. ${ }^{24}$

Amikor a két meginterjúvolt témagazda a Café előtt az egész kezdeményezést „púpnak és koloncnak" gondolta és nevezte, abban egyértelműen az a régi beidegződés érhetô tetten, hogy a biztonság csak a rendőrség, a rendőrök gondja. De ugyanezt fejezi ki a lakossági fórumokról alkotott véleményük is (lásd ezekre a korábbiakban már idézett „zsákutca, kínzókamra” kifejezéseket). Jóllehet a rendőrök és a civilek még messze nem beszélik a biztonság közös nyelvét, a lakossági fórumokat egyaránt unják, haszontalannak, kontraproduktívnak tartják. Talán a hagyományos rendőr-civil viszonynak ez a fajta elutasítása lehet az első közös pont, ahonnan mindketten elindulhatnak egymás, pontosabban a közös biztonságteremtés felé.

Körülbelül a rendszerváltással egyidős nálunk a „szubjektív biztonságérzet” kifejezés, amelyet még ma is előszeretettel használ mind a szakma, mind a köznapi ember. Nekem jó ideje gondom van vele, mégpedig amiatt a jelentéstöbblet miatt, amit maga a szó sugall. A „szubjektív érzet” azt jelenti: az egyének érzik vagy nem érzik, tudniillik

24 Molnár-Tamási (2019) 
azt, hogy biztonságban vannak vagy nincsenek. Mégpedig olyan biztonságban, amelyet mások adnak, „biztosítanak” nekik - kívülről, felülről, sokszor nélkülük döntve a róluk szóló kérdésekben. És meg is személyesül a biztonságot adó aktor: legfőképpen a rendőrség, illetve az állam más „rendfenntartó szervei”, illetve e szervezetek egyes tagjai, például a rendőrök ${ }^{25}$ vigyáznak ránk. Csakhogy éppen ez az évtizedek óta érvényesnek elfogadott nézet okozza, hogy a civilek a saját biztonságukért egyre kevesebbet hajlandóak tenni, amire viszont a rendőrök sokat panaszkodnak. Ez azonban nagyon is érthető, hiszen ha az emberek folyton azt hallják, hogy a biztonságteremtés a hatóságok, a rendőrség dolga, ők maguk egyre kevésbé érzik, hogy ők is tehetnének érte. Ám ha mindenki a másikra vár, a kör lassan be is zárul.

A saját biztonságunkért való tenni akarás csökkenése aztán szükségszerűen magával hozza a képességek, lehetőségek csökkenését is, hiszen ha az emberek leszoknak arról, hogy vigyázzanak magukra, nem gyakorolják a magukra és az egymásra figyelést, az éberséget, a segítókészséget, a szolidaritást, akkor ezekben nem szereznek jártasságot, rutint. A rendőrség azonban nyilvánvalóan nem képes mindenki biztonságát garantálni, azon őrködni, és ez - bármennyire furcsán hangzik is - nem is lehet dolga.

Ha a szubjektív biztonságérzet kifejezést a rendőrség szemszögéből nézzük, a következő a helyzet. A rendőrök legtöbbje csak azt tekinti a (köz)biztonságot javító eredménynek, amelyet tárgyiasult formában meg lehet jeleníteni (leginkább statisztikai módszerekkel mérhetően, adatolva, azaz objektíven). Az állampolgárok azonban nem ugyanúgy élik át, ítélik meg a rendőrség feketén-fehéren kimutatható sikereit. Kicsit olybá tűnik, mintha ezek a sikerek csak azt a célt szolgálnák, hogy a rendőrség igazolásképpen megveregethesse a saját vállát, hogy jól végzi a munkáját. Ezzel a kommunikációval azonban pont azt éri el, hogy a közösség egészen egyszerúen úgy tekint egy sor dologra, hogy az a rendőrség feladata, ahhoz ők értenek. A civilek sokszor nem is értik igazán, miről beszélnek a rendőrök, és már nem is akarják érteni: a biztonság az ő dolguk, vigyázzanak rá és kész. Közben persze, főleg ha nem érzik magukat biztonságban, a problémák miatt is a rendőröket okolják. A rendőrök körében pedig még mindig az a nézet az uralkodó, hogy az ő munkájukba nem kell mindenkinek belelátni, főleg nem beleszólni. Inkább gyerekként, alárendeltként kezelik az állampolgárt, mintsem partnerként. Ez aztán szükségszerúen mind nagyobb távolságot, hovatovább szakadékot keletkeztet közöttük, ami után nem is csoda, ha képtelenek egymással szót érteni. Elbeszélnek egymás mellett, és egyre nagyobb lesz a kommunikációs űr. Látszólag mindenki jól elvan a saját kommunikációs burkában, de valójában hamar rájönnek, hogy mennyire hiányzik a másik fél. A gond igazán akkor kezdődik, amikor a hétköznapok során felmerülő apróbb problémákat kellene nagyon egyszerűen, rugalmasan

\footnotetext{
A rendőr - magyar neve szerint - őrködik a renden. De miféle renden? Azon, amelyet ma is azzal a statikus rend fogalommal azonosítunk, amelyik már réges-régen nem érvényes. Állandó rend ugyanis nem létezik. Müködik helyette valami más. Mondjuk inkább így: egy állandó változásban lévő, vagyis dinamikus rendszer, amely ideális esetben egyensúlyban van, s élő emberek hozzák létre, tartják fenn vagy épp borítják fel, egymással szakadatlan kölcsönhatásban. A gondolat teljes kifejtése messzire vezetne és hosszú is lenne, itt most ennyi is elég a fogalom problematikusságának érzékeltetésére.
} 
és gyorsan megoldani. Ilyenkor üt vissza a kommunikáció - és ahogy fentebb mondtam, a közös nyelv - hiánya. Ilyenkor derül ki, mennyire más a megközelítése ugyanannak a problémának a rendőrök és a civilek felöl nézve.

A szubjektív biztonságérzet fogalmát tehát jó volna már kivezetni a használatból. ${ }^{26}$ A túlságosan hivatalos és inkább a rendőri szaknyelv részeként használatos közbiztonság ${ }^{27}$ helyett pedig a közös biztonságot javaslom. Ennek a közös biztonságnak bizonyos értelemben a párja egy másik fogalom, mégpedig a személyes biztonság lehetne. ${ }^{28}$ A biztonság személyes szintje az, amikor mindenki vigyáz magára és a körülötte élőkre, és e téren megteszi azt, ami tőle telik. Talán a legegyszerübb így mondani: igyekszik betartani a közösségi normákat az élet minden területén (együttélés, személyes higiéné és köztisztaság, közlekedés stb.). Mivel tudja, hogy ezzel nem feltétlenül van mindenki így, ezenfelül a helyi viszonyokhoz alkalmazkodva megteszi a szükséges elővigyázatossági lépéseket is a saját biztonsága érdekében: például kerítést épít, elzárja az értékeit, ha tudja, hogy számíthat lopásra, betörésre, hiszen ilyenek a környezetében előfordulnak. Ilyenkor a helyi biztonság a vagyon elleni bủncselekmények területén igenis deficites, ám az ellenük védekező egyén szubjektíve biztonságban érezheti magát, ha rácsokkal szereli fel lakását, leláncolja a kerékpárját, riasztót szerel az autójába. Vagyis ő maga tesz a személyes biztonsága érdekében. Egy ilyen értelemben „bűnügyileg fertőzött” területen a rendőrség vagyonvédelmi bünmegelőzési kampányt folytathat, ${ }^{29}$ térfigyelő kamerákat szerelhet fel, megerősítheti a járőrszolgálatot, hatékonyabbá teheti a felderítést stb., ám nem önmagában ettől lesz kevesebb a lopás, betörés, ha egyáltalán. Hiszen azok okaira ezek az intézkedések egyáltalán nem hatnak, legfeljebb kiszorítják az adott területről, így áttolódnak más, „kevésbé védett” területekre. Viszont az emberek szubjektív biztonságérzetére hatni kívánva elhitetik velük, hogy biztonságban vannak, miközben persze nincsenek.

Azokban a kultúrákban, ahol körülkerítetlen házakat, nyitott lakásajtókat látunk, a lakosoknak valószínüleg nincs okuk félni a lopástól, betöréstől, mert ilyenek nem fordulnak elő, így nem is védekeznek ellene. És ez nem szubjektív biztonságérzet, vagyis ez nem azt jelenti, hogy úgy érzik, hogy nem kell védekezniük a lopás, betörés ellen, hanem - mivel nincs lopás és betörés - valóban biztonságban vannak az értékeik és ők maguk is.

És ugyanennek az ellenkezője is igaz lehet. Van, amikor egy-egy lokalitás közössége jól érzi magát, biztonságban van, nem történnek különösebb bűncselekmények, ám egy hirtelen búneset megingatja ezt az egyensúlyt. Ha ilyenkor a rendőrség rosszul cselekszik, azaz eltúlozza a beavatkozást, akkor ok nélkül fokozhatja az emberek félelmét. Vagyis a hatóság nem adekvát fellépése szubjektíve ott is biztonságérzet-deficitet

26 A szubjektív biztonságérzet értelmezéséhez lásd: Krémer (2011) 216-220.

27 Lásd ehhez: Krémer (2009) 62-90.

28 A személyes biztonság és a közös biztonság fogalmának meghatározását az alábbi forrásból merítem: Krémer (2018). De lásd még ehhez: Walklate (2001).

29 Ezt a tájékoztató munkát a magyar rendőrség évtizedek óta végzi, meglehetősen nagy erőket és forrásokat biztosítva hozzá. A bűnmegelőzésnek nem kifejezetten hatékonynak tartott válfaját képviselik a legkülönfélébb szóróanyagok, tájékoztató füzetek, kiadványok. 
képes keletkeztetni, ahol egyébként erre egyáltalán nincs ok. Pontosan ez történt Pécsett 2012-ben Bándi Kata megölése után. Ezért is volt hatástalan a szokásos reakcióként hozott intézkedések sora, például a megerősített rendőri jelenlét, amitől nem hogy nyugodtabbak lettek volna a lakosok, de még azok is félni kezdtek, akik azelőtt nem. A logika szerint ugyanis, ha ilyen sok rendőr van az utcán, akkor nyilván baj van. És az ördögi kör bezárult...

A szubjektív biztonságérzet kifejezést ideje volna tehát felváltani a személyes biztonság, a közbiztonságét pedig a közös biztonság fogalmával. Ez utóbbinak a szinonimái lehetnek még a települési biztonság, a lokális biztonság vagy az élhető, biztonságos közösség kifejezések is. Ezek azt jelentik, hogy a kisebb-nagyobb közösségek tagjai együtt, egymással konszenzusra jutva, aktívan, felelősségteljes hozzájárulásaik révén tehetnek és tesznek is a közös biztonságuk érdekében. Mégpedig minden szereplőt beleértve, mindenki a saját kompetenciájának megfelelően: például a lakók azzal, hogy nem szemetelnek, hogy elsöprik a havat a házuk elől; a köztisztasági cégek a rendszeres szemétszállítással és a közterületek takarításával; a közlekedésfelügyelet a forgalom megszervezésével; az önkormányzat a közvilágítással stb. És a szereplők közül a rendőrség csak egy. Persze ő kiemelten fontos, de kizárólag azért, mert az ő kezében van a kezdeményező és a koordináló szerep, hiszen az ő szakmája a biztonság, s mert államilag is ő hivatott erre.

Essék szó végül egy másik aspektusról is, amelyik a képzőé és moderátoré. Talán az övé a legszerényebb sikerkritérium. Annak az apró dolognak is tud ugyanis örülni, ha a rendőrök megtanulnak valami újat az egymással és a civilekkel való kommunikáció mikéntjéről, aminek köszönhetően egyre többször tudnak leülni egymással előremutató párbeszédet folytatni - a helyi biztonság fent kifejtett fogalma szerinti - közös dolgaikról, ügyeikről. Ha az erre egyébként meglévő igényeik összetalálkozhatnak, ha a párbeszédek nyomán elkezdenek egyeztetni, véleményt, információkat cserélni, ötletelni és cselekedni, az már siker. Ezeknek a legkellemesebb fórumai lehetnek a rendőkávéházak. Ha ugyanis a közösség tagjai egyre gyakrabban megélik, hogy a megoldásokat csak közösen lehet kialakítani, ehhez pedig érdemi párbeszédre van szükség, nagyobb az esélye, hogy egyre több mindenben egyeztetnek, tárgyalnak egymással. Ez pedig - ahogy az egyik kapitány fogalmazott - szinte „automatizálja a közös problémamegoldás folyamatát".

\section{Konkrét eredmények}

A témagazda rendőrök úgy látják, hogy a Cafék legnagyobb hozadéka a személyes kapcsolatok létrejötte, illetve a már meglévők aktivizálódása. És nemcsak a rendőrök és a civilek közötti, hanem a civilek egymás közötti kapcsolatait is ideértik. Mihelyt a hivatal, a szervezet, az intézmény megszemélyesül, és egy konkrét arc társul az aláírás, a címzés vagy a telefonszám mellé, az azonnal elkezdi olajozni az addig esetlegesen csikorgó, akadozó együttműködést. Néhány „rendőrkávézás” pár órás közös élménye már önmagában összekapcsolja a résztvevőket. Ez aztán jó hivatkozási alap, amelyre 
tovább lehet rakosgatni a bizalom kisebb-nagyobb építőkockáit, s végül a partnerségből közös megoldások is születnek. A konkrét eredményekről az interjúkban örömmel és elégedetten számoltak be mind a rendőrök, mind a civilek. Az interjúkészítő számára persze érdekes élmény, amikor egy-egy történet két-három interjúalanynál is visszaköszön. Pécsett az egyik megvalósult példa konkrétan egy háztető felújítása volt, ami egyszerú ügy, az érintetteknek mégis fontos és szimbolikus.

A rendőr nem is lenne rendőr, ha nem az információ lenne számára a legfontosabb kincs. Igaz ez a „kávézgató” rendőrökre is, és ez teljesen rendben van. Kivétel nélkül minden nyilatkozó rendőr hallott a Cafékban értékes és új bünügyi információkat. Ezek lehetnek utcai zaklatások, a közterületen szanaszét heverő fecskendők, betört ablakok, eltűnt személyek, feltört gépjárművek, elhagyott lakások, amelyekről egyébként normális esetben értesíteni kellene a rendőrséget, de a lakosok mégsem teszik. Ugyanezt erősítették meg a civilek is, csak a másik oldalról. Ők a rendőrkávéházakban jutottak hozzá olyan ismeretekhez, információkhoz, amelyeket a rendőrség működéséről, a rendőrök munkájáról réges-régen tudniuk kellene. Felvetődhet, hogy miért kell ehhez Police Café? Ám ha ez kell, rendezzünk minél többet! Beszélgetőtársaim azt mondták, jó lehetőségnek látják a Cafékat arra is, hogy a rendőrség bizonyos üzeneteket közvetve, finoman eljuttasson a civilekhez, amelyeket máshol, máskor, mástól egyébként nem hallanak meg.

A kutatásban vizsgált sorozatok lezárása óta eltelt öt, két és fél, illetve másfél év alatt sok minden történt. Az utóhatásokról és a Police Café utóéletéről minden interjúalanynak tudomása van, sőt, mindegyiküknek személyesen is volt kisebb-nagyobb szerepe a továbbvitelben. Időrendben haladva és a három vizsgált lokalitásra lebontva lássunk néhány konkrét eredményt, rendezvényt.

\section{Baranya megye}

- Az első Police Café sorozat Pécsett láthatóan katalizálta a Közbiztonsági Tanács múködését. A szúkebb értelemben vett rendészeti szervezetekhez képest kiszélesítette azoknak a körét, akik a város biztonságáért felelösséggel tartoznak, és azt magukra is vállalják. Ezt a rendőrkapitány és a civil interjúalanyok is így vélik. Legékesebb „tárgyi bizonyítéka” ennek a „Pécs Megyei Jogú Város Önkormányzatának közbiztonsági és bűnmegelőzési koncepciója 2017-2023" címú 25 oldalas dokumentum, amelyet a kidolgozásban oroszlánrészt vállaló városrendészeti bizottsági tag hozott el az interjúra. A koncepció végrehajtásához a 2017. május 1. és 2019. május 31. közötti időszakra vonatkozó 6 oldalas Cselekvési program is társul. S hogy még meggyőzőbb legyen a tény: egyúttal kezembe adta a Cselekvési program feladatainak végrehajtásáról szóló beszámolót is, amely szintén 6 oldalban, 18 pontban sorolja a 2017. május 1. és 2018. május 1. között végzett tevékenységeket. Elmondása szerint ennek létrejöttében kifejezetten nagy szerepe volt a 2014-es Police Café sorozatnak. Bár a szöveg még erősen magán viseli a hagyományosan 
hivatalos stílusjegyeket, és fogalomkészlete is a biztonság egy korábbi, mára kissé megkopott koncepciójához áll közel (lásd a szubjektív biztonságról kifejtett Tisztázandó alapfogalmak alfejezetet), mégis, üdvözlendő, hogy elkészült, létezik, megismerhető, vitatható és évről évre tovább fejleszthető, alakítható, aktualizálható. Igazán előremutató az lenne, ha ezt a munkát is közösségi alkotótechnikával végeznék.

- Mindig lépéselőnyben lévén, Pécs volt az első ismétlő is. Napra pontosan egy évvel az első Café képzés után, 2015. május 12-én a módszert elsőként elsajátító pécsi rendőrök a budapesti VIII. kerületből érkező kollégáiknak tanították meg a módszert egy Rendőr Police Caféban. ${ }^{30}$

- Szerencsére Pécsett a 2014-es rossz széria óta nem alakult ki olyan haváriahelyzet, amely gyors beavatkozást igényelt volna. 2016. november 9-én azonban egy konkrét helyi igényre - a hatalmas létszámú külföldi diák problémamentes együttélésének segítésére - reagáltak a rendőrök, amikor Egyetemi Police Cafét szerveztek a Pécsi Tudományegyetemen. ${ }^{31}$

- Az Egyetemi Café után egy évvel a Járási Police Café müfaja született meg ismét Baranyában: Bólyban és Sásdon 2017. november 7-én és 8-án az évente megtartandó szokásos közbiztonsági egyeztető fórumokat váltottuk fel az interaktívabb közösségi párbeszéddel. ${ }^{32}$

\section{Bács-Kiskun megye}

- Bács-Kiskun megye 2016-ban először csak kísérlet gyanánt rendezett három Cafét (Jánoshalmán, Kiskunhalason és Kiskunmajsán), amelyeket a sikerre való tekintettel egy év múlva már egy komolyabb, szintén pályázati forrásból megvalósított hétrészes sorozat követett, ezúttal a megye hét nagyobb városában: időrendben Kunszentmiklóson, Kalocsán, Baján, Kiskunhalason, Kecskeméten, Kiskunfélegyházán és Kiskőrösön.

- Kiskunhalas 2017-ben már eleve ismételt, de újra szervezkedésbe fogtak, és 2017. október 3-án megtartottuk a harmadik Halas Cafét. ${ }^{33}$

- A Bács-Kiskun megyeiek engem is megleptek: 2017. december 8-án pár órára önkiszolgáló rendőrkávéházat nyitottak Kiskunmajsán, aminek felettébb örültem, hiszen ez azt bizonyította, hogy magabiztosan megtanulták a módszert, és azt képesek önállóan is alkalmazni arra, amire épp szükségesnek látják. ${ }^{34}$

- Kiskunhalason a Területi Kistérségi Koordinációs Munkacsoport a sokéves „tetszhalott” állapotából megmozdulni látszik. A szokásos évi két ülésén

\footnotetext{
Lásd erről: http://policecafe.hu/police-cafe-pecs-budapest-2-1/ (2019. 07. 01.)

Lásd erről: http://policecafe.hu/police-cafe-pecs-par-orara-ujra-nyitva/ (2019. 07. 01.)

Lásd erről: http://policecafe.hu/jarasi-kozbiztonsagi-egyezteto-forum-es-police-cafe-bolyban-es-sasdon/ (2019. 07. 01.)

Lásd erről: http://policecafe.hu/eloszor-masodszor-kiskunhalas-harmadszor/ (2019. 07. 01.)

Lásd erről: http://policecafe.hu/onkiszolgalo-police-cafe-kiskunmajsan-az-elso-police-cafe-kepeslapom/ (2019. 07. 01.)
} 
2018-ban már a kapitány is megjelent, és közvetlenebb hangnemben, őszintén beszélgettek a problémákról, amit nagyon jó néven vettek a résztvevők. A kapitány azt tervezi, hogy a következő ülést már Café módszertannal bonyolítják le.

- A kiskunhalasiak 2018. november 22-én a Járási Közbiztonsági Egyeztető Fórum 35 résztvevőjét is Police Caféba invitálták, teljesen önállóan. ${ }^{35}$

- Szintén Kiskunhalason Roma Police Café címmel 2018. december 6-án a helyi Roma Közösségi Házban rendezték az első, konkrétan ilyen jellegú párbeszédet, 26 vendég részvételével. ${ }^{36}$

- És még nincs vége. 2019. május 6-án, szintén az országban elsőként Diák Police Cafét $^{37}$ tartottunk Kiskunhalason két általános iskolában. 20-20 hetediknyolcadik osztályos tanulót láttunk vendégül - kávé helyett stílszerűen teára és zsíros kenyérre -, és négy rendőr beszélgetett velük a sajnos egyre inkább ezt a korosztályt is érintő kábítószer-problémáról. A kapitány tervei szerint 2019 őszén a többi iskolába is elviszik a programot.

\section{Zugló}

Az akkori budapesti főkapitány a zuglói Police Café sorozat záró rendezvényének díszvendégeként valahogy így fogalmazott: „Egy 21. századi rendőrségnek a 21. század biztonsági kihívásaira adott 21. századi válasza - ez a Police Café." A megtisztelő vélemény nyomán kis ideig úgy tűnt, hogy szerette volna kötelező jelleggel a többi kerületi kapitányságra is kiterjeszteni a módszert, de - teszem hozzá: szerencsére - ez csak jámbor óhaj maradt. Néhány kerületi kapitány addig mutatott érdeklődést a program iránt, amíg ki nem derült, hogy az mégsem lesz kötelező. Budapesten azóta sem rendezett senki más Police Cafét, csak a zuglóiak aktivizálták magukat és a civileket. Nézzük, mit valósítottak meg:

- Zuglóban a nyolc körzet közül az utolsóba tervezett Café másképpen alakult, mint eredetileg szerettük volna: a sorozat zárórendezvénye lett, ahova az egész kerület érintettjeit meghívtuk, sőt, más kerületekből is érkeztek vendégek. Ezért a körzet saját (pót) Caféját Liget Café néven rendeztük meg 2017. november 21-én, ${ }^{38}$ ami így tulajdonképpen már a programsorozat folytatásaként a 9. Cafénak volt tekinthető.

- Igazibb utóhatásnak azonban az időrendben következő, a 2017. november 28-án tartott Pedagógus Café számít, amelynek gondolata egy Police Caféban

\footnotetext{
35 Lásd erről: http://policecafe.hu/police-cafe-extra-9-halas-cafe-kepeslap-jarasi-kozbiztonsagi-egyezteto-forum-maskent-immar-bacs-kiskunban-is/ (2019. 07. 01.)

36 Lásd erről: http://policecafe.hu/mikulas-napi-meglepetes-roma-police-cafe-kiskunhalason/ (2019. 07. 01.)

37 http://policecafe.hu/diak-police-cafe-kiskunhalason/ (2019. 07. 01.)

38 Lásd erről: http://policecafe.hu/police-cafe-liget/ (2019. 07. 01.)
} 
részt vevő tanár fejében született meg. A civilek saját belső szervezeti viszonyaik megvitatására rendezték meg a rendhagyó párbeszédet. ${ }^{39}$

- 2018. június 4-én a zuglói 6-os körzetben a Rákosszeg Caféra ${ }^{40}$ került sor, ahol a Rákosszeg és Sárrét park és lakótelep (többek között közbiztonsági szempontú) területfejlesztését is napirendre tűzték, és a rendőrök mellett az önkormányzat főmérnöke is témagazda szerepet vállalt. A két szervezet együttmúködésének erősítésén túl jól példázza mindez a (köz)biztonság fogalmának sok szempontú megközelíthetőségét is. Az alkalom hatására 2018 novemberében Zugló közbiztonságáért felelős alpolgármesterének bevonásával egy több körzeten is átnyúló területfejlesztési terv megbeszélése is lezajlott az érintett intézmények, szakemberek meghívásával. A körzeti megbízottak meglátásaira is számítottak a fejlesztési tervek kidolgozása során. ${ }^{41}$

- A meginterjúvolt szociális szakember konkrét eseteket is sorolt, amelyeknek a megoldásához vezető út a Caféban kezdődött. Mégpedig azzal, hogy ott vált magától értetődővé a bizalom a rendőr és a szociális szakma képviselői között. Az egyik esetben egy súlyos krízishelyzetben lévő, a férje fegyveres fenyegetését elszenvedő anya és gyermeke sürgős kimenekítését kellett pillanatok alatt megoldani, és a rendőrök ezt gyorsan és szakszerúen intézték, egyetlen hívó szóra. A másik egy elhúzódóbb probléma volt: egy többször öngyilkossági kísérletet elkövető drogos fiatalkorú ügyében kellett esetmegbeszélést összehívni, amelyen a rendőrök szintén hatékonyan vettek részt.

- Mindez szerinte arra is jó, hogy a rendőr fontos visszajelzést kaphat arról, hogy szociálisan érzékenynek lenni jó. Hiszen a még mindig túlzottan maszkulin rendőri szubkultúra nem ritkán inkább a kemény, harcias, marcona rendőrt „díjazza”. A segítésből fakadó emberi érzés motiváló, a sikerélmény inspiráló. A rendőrök kiégéséhez véleménye szerint több dolog is vezet. Az egyik az, ha a hétköznapokban nem élhetik meg a rendőri munka segítő, szolgáltató mivoltát. A másik, ha az egyes helyzetekben képtelenek megoldást találni, ha sorozatos kudarcot kell megélniük. A harmadik, ha úgy érzik, magukra maradnak. Az efféle sikertörténetek éppen ezen a három területen hoztak sikerélményt a rendőröknek, ezért gondolják, hogy valamelyest visszakapták a szakmájukba, a rendőri munkába vetett, az utóbbi években igencsak megtépázott hitüket.

- A legizgalmasabb és talán a legnagyobb visszhangot kiváltó utóhatás: Az ECPA 2018 (Európai Bünmegelőzési Díj) ${ }^{42}$ legjobb európai gyakorlatokat felvonultató mezőnyében a 2018. december 4. és 6. között Bécsben rendezendő konferencián a zuglói „Szomszédom a rendőr!” projekt és annak meg-

39 Lásd erről: http://policecafe.hu/szervezetfejleszto-kavehazat-nyitottak-egy-zugloi-iskolaban/ (2019. 07. 01.)

40 Lásd erről: http://policecafe.hu/zuglo-folytatja-a-masodik-police-cafe-kepeslapom/ (2019. 07. 01.)

${ }^{41} \mathrm{Az}$ interjúk elkészítése óta eltelt időben már ezen a rendezvényen is túlvannak a lelkes zuglóiak. Itt olvasható róla egy rövid beszámoló: http://policecafe.hu/police-cafe-extra-6-ujabb-cafe-kepeslap/ (2019. 07. 01.)

42 Lásd: https://eucpn.org/events/european-crime-prevention-award-ecpa-and-best-practice-conference-bpc (2019. 07. 01.) 
határozó elemeként a Police Café képviselte Magyarországot, és az igencsak erős nemzetközi mezőnyben a 3. díjat kapta. ${ }^{43}$

- S végül: e tanulmány kéziratának lezárásához közeledve, 2019. április 5-én Zugló legaktívabb körzeti megbízottja, Tomis Károly és a ZKNP projektkoordinátora, Adler Katalin az első önálló rendezvényüket is megtartották: ez volt a kulturális sokféleség konfliktusmentes együttélése témakörében az országban az első Roma-Police Café.

Mindezek egyenként és együttesen is a Police Café céljaival egyező, innovatív hatások, mert

- a közösségi párbeszéd módszertanának továbbadását (Rendőr Police Café Pécsett);

- a módszer önálló alkalmazását, az azt megtanuló és begyakorló szakemberek saját lábra állását (önkiszolgáló Police Café Kiskunmajsán, Rákosszeg Café és Roma-Police Café Zuglóban);

- a közösség konkrét, egyedi biztonsági problémáira való ilyesfajta reagálást (Egyetemi Police Café Pécsett, Diák Police Café Kiskunhalason);

- a módszer tudatos földrajzi kiterjesztését (a zuglói 8+1 és a Bács-Kiskun megyei 7 részes sorozatok, valamint a Járási Police Cafék Bólyon és Sásdon);

- egy-egy korábban múködő, a helyi biztonságért dolgozó, de elakadt munkacsoport, bizottság újraéledését (Pécsett és Zuglóban);

- a módszernek a civilek számára is kedvet csináló mivoltát (Pedagógus Café, Rákosszeg Café és Roma-Police Café Zuglóban, Diák Police Café Kiskunhalason);

- a lakossági fórumok múfajának leváltását (a Járási Police Cafék Bólyban és Sásdon);

- valamint konkrét krízishelyzeteknek a rendőrök és a civilek gyors és hatékony együttműködésen alapuló megoldását érhetjük tetten bennük.

\section{Hogyan tovább, Police Café?}

\section{Lakossági Police Cafék}

A nyilatkozó témagazda rendőrök felidézték, hogy hányszor kerülnek különböző lakossági fórumokon a szokásos frontális előadások „vakvágányára”, amikor menetrendszerúen bejön minden hatás, ami ilyenkor szokott. Jóformán végig se hallgatják a rendőr mondandóját, egyből nekitámadnak, vitába keverednek, és eredménytelenül zárul a találkozás. A tipikus lakossági fórumot egyenesen a rendőrök „rémálmának” nevezték az interjúalanyok. Persze van, hogy sikerül a hangadót leszerelni, de mire

\footnotetext{
43 Lásd erről: http://policecafe.hu/police-cafe-extra-10-mikulas-napi-meglepetes-ii-becsben-is-a-szomszedom-a-rendor/ (2019. 07. 01.)
} 
ide eljutnak, sok energiába és időbe, netán vitába és veszekedésbe telik. Megismerve a Police Cafét, rájöttek, hogy legközelebb talán jó lenne ezzel a módszerrel próbálkozni, hátha segítene felébredni ebből a rémálomból. Kíváncsian várom, ki lesz olyan bátor, hogy megrendezi az első igazi, konkrét problémára reagáló lakossági Police Cafét. Egy próbajáratot - az Egyetemi Police Cafét ${ }^{44}$ - a pécsi rendőrkapitányság már felmutathat ezen a téren.

A civilek között a polgárőr szövetségi elnök tette föl nekem azt a kérdést, hogy mennyire lehet bővíteni a meghívottak körét és konkrét létszámát. Erre nincs konkrét válasz. Amit jelenleg a tapasztalatom alapján tudok mondani, az egy 70 résztvevős (nem Police) Café volt, 7 asztallal, 7 témával, 7 témagazdával, 4 óra időtartamban. ${ }^{45}$ Ez akár lakossági Police Caféban is megoldható lenne, és alig várom, hogy kipróbáljam.

\section{Police Cafék rendörvezetöknek}

Hosszabb távú terv lehet egy Vezetői Police Café megrendezése. Nagyon fontos volna ugyanis összehozni a saját szakterületeikre komoly ráhatással bíró rendőri vezetőket - akár lokális, akár regionális, akár országos szinten -, és megismertetni őket ezzel a módszerrel, hiszen minden bizonnyal egyáltalán nem, vagy csak kevesen tudnak róla. Márpedig, ahogy a meginterjúvolt három rendőrkapitány pozitív példáján látható, a vezetőknek óriási a szerepük abban, hogy meglátják-e egy-egy módszerben a lehetőséget.

Itt érdemes hangsúlyozni, hogy az eredeti World Café 7 alapelvéhez képest a Police Café hazai tapasztalatai alapján 3 további alapelvet tartottam szükségesnek lefektetni (lásd: 1. ábra).

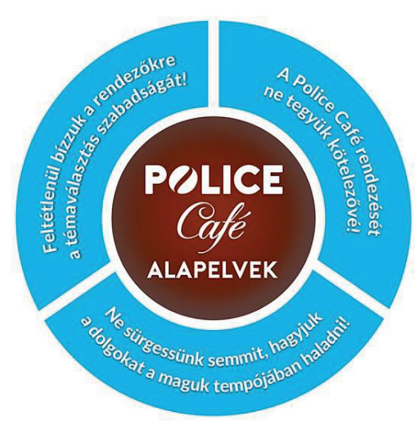

1. ábra: A Police Café alapelvei. Forrás: http://policecafe.hu/vedjegy-police-cafe-alapelvek/ (2019.07.01.)

44 Lásd erről: http://policecafe.hu/police-cafe-pecs-par-orara-ujra-nyitva/ (2019. 07. 01.)

45 A budapesti VIII. kerületi Magdolna-Orczy Negyed Program előkészítő szakaszának egyik nyitó rendezvényéről van szó, amelyet 2018. június 20-án tartottunk. A leírását lásd itt: http://policecafe.hu/morczy-cafe-i-ii-iii-kell-egy-csapat/ (2019. 07. 01.). 
Amiért ez egyáltalán felmerült, az a jelenleg dominánsan érvényes rendőri vezetői attitűdökből fakadó felismerés, miszerint egy centralizált irányítású, erősen hierarchikus, félkatonai szervezetben regnáló vezető bármit könnyedén hajlamos kötelezővé tenni, sürgetni és uniformizálni, amiről feltételezi, hogy jó hatással lehet. És teszi mindezt akár a legnagyobb jó szándékkal. Márpedig ez a három beavatkozás - a kötelezővé tétel, a sürgetés és az uniformizálás - a Police Café típusú módszereket teljesen kontraproduktívvá tennék.

Nagyon fontos, hogy a felelős rendőrvezetők megértsék a civilekkel való kapcsolattartás fontosságát, legyenek tisztában az ennek hatékonyságához szükséges kommunikáció szerepével. A rendőrségnek mint szervezetnek pedig legyen kiemelt célja, hogy a közösségi párbeszédre alkalmas módszerek minél nagyobb számban és bárki számára elérhető módon álljanak rendelkezésre. Legyen természetes, hogy a helyi vezetők kedvükre választhassanak e módszerek közül, és a használatukhoz szükséges minden készség szervezetten megtanulható legyen. A Police Café e módszerek egyikeként a több mint egy éve múködő http://policecafe.hu honlapon keresztül megismerhető. Az egynapos, 8 pontot érő akkreditált képzés „Police Café - módszertani és kommunikációs képzés rendőröknek” néven a Belügyminisztérium Vezetőképzési, Továbbképzési és Tudományszervezési Főosztály ${ }^{46}$ továbbképzési rendszerében 2016 tavasza óta elérhető. ${ }^{47}$

\section{Szervezetfejlesztö Cafék}

$\mathrm{Az}$ öt vidéki rendőr interjúalany szerint az egyes őrsökön dolgozó kollégák, illetve az őrsparancsnokok és más, a városi kapitányságon dolgozó vezetők közötti kapcsolatok náluk (már) nagyrészt rendben vannak. Mégis egybehangzóan úgy nyilatkoztak, hogy a Café alkalmak segítettek még azokat a falakat is tovább bontani, amelyek a hierarchiából fakadóan főleg a vezetők és a beosztottak között megvannak. És ugyancsak jót tett, amikor látták egymás kommunikációs „átváltozását”, az aktivitás, a motiválás kisebb-nagyobb jeleit.

A témagazda őssparancsnok érdekes példával világította meg a belső szervezeti kommunikációhoz való saját viszonyát. Korábban, még a rendőrség előtt olyan munkahelyen szocializálódott, ahol nem a parancsuralmi viszonyok domináltak, így amit csak lehet, igyekszik onnan átmenteni. Beosztottjait munkatársaknak tekinti, bizalmuk, egymás iránti tiszteletük kölcsönös, amit a 40 emberből álló csapatában állandóan ápol, fejleszt. Ebből a szempontból számára ez a módszer kifejezetten üdítő volt, hiszen itt ugyanezt gyakorolhatták. A Café asztalainál zajló beszélgetésben nem számított, hogy a hierarchia mely pontján álló (ülő) rendőr mond éppen valamit, mert ez a „kávéházi” környezet kiegyenlíti az egyébként felbillent viszonyokat. A belső szervezeti kommunikáció szempontjából egyértelműen ezt tartja a módszer legnagyobb

\footnotetext{
46 A szervezet korábbi neve Közszolgálati Személyzetfejlesztési Főigazgatóság. https://tovabbkepzes.bmkszf.hu/\#!login (2019. 07. 01.)

47 A képzés nyilvántartási száma: 3/M/2016/5468. Akkreditálta a Nemzeti Búnmegelőzési Tanács.
} 
hozadékának. Ezt sorozatosan, napról napra (Pécs), hétről hétre (Zugló), hónapról hónapra és évről évre (Bács és Baranya megye) megélni biztosan jó út ahhoz, hogy a rendőrkávéházban kialakult nexusból a napi hivatali munkakapcsolatokba is át lehessen csempészni valamit.

A kiskunhalasi kapitány szerint a Café nagyon jót tett a szervezeten belüli információáramlásnak. De nemcsak annak. Sokkal fontosabb volt, hogy a Police Café nyilvános gondolkodási platformként hozzásegítette a vezetőket egy közös értékrend kialakításához. Egymással és vele mint kapitánnyal is közvetlenebb kapcsolatba kerültek. Arról nem is beszélve, hogy úgy látja, vezetőtársainak a problémákhoz való viszonyában is komoly változás következett be. Nem érezte túlzásnak azt állítani, hogy vezetőként egy újabb motiváló eszközt kapott a kezébe. Az ehhez nélkülözhetetlen bizalom kiépítését, a vele mint új vezetővel szemben eleinte szükségszerűen meglévő fenntartásokat a Police Cafék hamarabb segítettek megszüntetni. Határozottan állítja, hogy ha nincs semmi konkrét cél, akkor nem „kell” mindenáron Police Cafét rendezni. (Lásd az 1. alapelvet: „A Police Café rendezését ne tegyük kötelezővé!”) De ha a civilekkel nincs éppen felmerülő kérdés vagy probléma, amiért érdemes őket összehívni, akkor a kollégákkal is összeülhetünk ilyen módon. Saját tapasztalata alapján kifejezetten alkalmasnak tartja a Café módszert belső szervezetfejlesztésre is, hiszen egy adott téma olyan minőségű és mélységű, valódi, tartalmas feldolgozását teszi lehetővé, amilyet ő semmilyen más technikával nem tapasztalt.

\section{Nemzetközi vizeken}

A 2018. november 28-30. között Budapesten "Innovations in law enforcement - Implications for practice, education and civil society" (Rendészeti innovációk és hatásuk a gyakorlatra, az oktatásra és a civil társadalomra) címmel a CEPOL ${ }^{48}$ nemzetközi konferenciát tartott. Mivel a Police Café céljai és módszertana tökéletesen illettek a konferencia profiljába, 2017. november 29-én a 19. szekcióban immár egy nemzetközi rendészeti tudományos fórumon is bemutatkozhatott a módszer. Egy év elteltével ugyan, de végül az European Law Enforcement Research Bulletin 2018. évi októberi számában megjelent az előadás szerkesztett változata ${ }^{49}$ is. Így a magyarországi Police Café az európai rendészet színes módszertani kínálatában is megjelenhetett. Reméljük, hogy ez az immár harmadik ${ }^{50}$ nemzetközi bemutatkozás nem az utolsó lesz. Mert természetesen további terveink is vannak.

\footnotetext{
48 The European Union Agency for Law Enforcement Training. A CEPOL egy európai uniós ügynökség, amely képzések révén támogatja az európai és nemzetközi bűnüldözési együttműködést. www.cepol.europa.eu/ (2019. 07. 01.)

49 Molnár-Uricska (2018)

50 Gaál-Molnár (2017) 58-63.; Gaál-Molnár (2015) 71-78.
} 
2018. november 5-e óta a nemzetközi World Café közösség honlapjának Global Map felületén ${ }^{51}$ is megjelent a The Police Café Hungary felirat. A nemzetközi érdeklődésre számítva pedig a közeljövő tervei között az is szerepel, hogy a magyar nyelvű http:// policecafe.hu/ honlapon egy rövid angol nyelvű módszerleírást is megjelentetünk.

S végül: 2019 áprilisában - egy kedves baráti születésnapi meglepetésként ${ }^{52}$ - megjelent a Police Caféról szóló első önálló kötet Rendőrkávéházi élményeim ${ }^{53}$ címmel.

\section{A civilek javaslatai}

Talán jellemző, hogy egy magasan pozícionált vezető fogalmazta meg, hogy ő igényelte volna a témák előrejelzését már a meghívóban, hogy a résztvevők egy kicsit felkészülhessenek. A módszert öt éve gyakorlóként az a meggyőződésem, hogy ennek lehet létjogosultsága, de van, amikor kifejezetten a spontaneitás a kívánatos. Ha valahol az első Cafét rendezzük, mindenképpen az utóbbi igaz.

Ha viszont már a többedik Caféra hívjuk meg ugyanazokat a résztvevőket, az előzetes felkészülés is elvárható. A nagyobb időintervallum után többedszerre visszatérők kifejezték: igényelnének egy rövid emlékeztetőt, összefoglalást, reflexiót az előző Café óta eltelt időszakban történtekről, főleg azokról a javaslatokról, amelyek megvalósultak, vagy éppen nem, és hogy miért. Egyikük szerint akár félévenként jó lenne összejönni, és visszatérni az első találkozáskor felvetett problémákra.

Az egészségügyi szektort képviselő interjúalany egy nagyon sajátos szempontot hozott a beszélgetésbe. Nyilvánvaló, hogy sok kriminális cselekmény érintettje az orvosnál, az egészségügyben köt ki, így az ott dolgozó szakemberek rengeteg információhoz juthatnak. Az orvosi titoktartás diszkrécióra kötelezi az egészségügyi dolgozókat, és ettől kezdve komoly szakmai, jogi és etikai dilemma, hogy a tudomásukra jutott információkkal mit kezdenek. Jónak tartaná, ha ezekről egy általánosabb szinten, konkrétumok nélkül tudnának beszélgetni, akár egy Café módszerü fórumon is.

$\mathrm{Az}$ interjút adó szerkesztő pedig a Police Cafét mindazoknak a rendőröknek ajánlja, akik „nyitni szeretnének a civilek felé, változtatni szeretnének a rendőrség megítélésén".

\section{Záró gondolatok}

Mint a Police Café magyarországi kidolgozója és terjesztője, biztos vagyok benne, hogy ez a kutatás sok információval gazdagítja az érdeklődőket. De azt is szeretném hinni, hogy meggyőző érvekkel is sikerült hozzájárulnom ahhoz, hogy a Police Café módszerben egyre többen meglássák azt a lehetőséget, ami nekik is segíthet olyan eredmények elérésében, amelyekről a kutatásban megkérdezett rendőrök és civilek beszámoltak.

\footnotetext{
51 A térképen Magyarországra közelítve és a jelölésre kattintva jelenik meg a rövid leírás. www.theworldcafe.com/globalimpact/ (2019. 07. 01.)

52 Lásd erről: http://policecafe.hu/police-cafe-extra-15-konyvajanlo/ (2019. 07. 01.)

53 Molnár (2019)
} 
A tanulmány zárásaként szó szerint idézek az egyik vezetői interjúból: „3 éve dolgozom Kiskunhalason, és 3 év alatt egy rendkívül magas fokú elégedettséget értünk el a közösségen belül. És én meg vagyok arról győződve - és ezt nem »csak úgy« mondom, hanem tényleg hiszek benne -, hogy igenis köze volt ennek az elismertségnek, ennek a fajta beágyazottságnak a Police Caféhoz. Ez ugyan nem mérhető, jelenleg úgymond fókuszon kívüli módszer. Amikor leülünk és beszélgetünk, az egy humán megközelítése a problémának. De ezzel együtt az erősen ajánlott kategóriába sorolnám vezetőknek, különösen kezdő vezetőknek. És érzékenyítő hatása is van: arra sarkallja a vezetőt, hogy nyisson a saját közössége irányába, ami egy nagyon jó és fontos dolog.”

Mielőtt még bárki elfogultsággal vádolja a nyilatkozót vagy az elemzőt, gyorsan hozzáteszem, hogy ez persze csak akkor működik, ha a helyi rendőrök között a módszer befogadó és egyúttal értő fülekre talál. Vagy így is mondhatnánk: a „rendőrkávé” csak a megfelelő kávémesterek (rendőrök) kezébe kerülve hat. És persze lehet irigyelni azokat, akik kipróbálták, és ahol hatott, de hogy ebben mennyi energia van, azt talán érzékeltették a nyilatkozók szavai. Eldönteni, felvállalni, megtanulni, megszervezni, megrendezni, kipróbálni, értékelni, aztán ismételni, fenntartani, variálni, megújítani, tovább fejleszteni - ezek a siker apró lépései. Ezeket egyenként és az interjúkban végigtekintve, illetve így most összegezve is tetemes munka sejlik fel a háttérben. De a megtérülés még nagyobb: egy bizalommal telibb, ezért együttműködőbb, tehát élhetőbb és ettől biztonságosabb közösség, amelynek a rendőr is fontos, megbecsült tagja.

A Police Café módszer és jelen tudományos igényú feldolgozás a közszolgáltatók közönségkapcsolatainak egy egészen új minőségét kívánja bemutatni, ami nyilván általánosítható lenne más szektorokra is (oktatás, szociális ellátás, egészségügy, közterület-fenntartás stb.). ${ }^{54}$ Meggyőződésem, és a nemzetközi gyakorlat is ezt mutatja, hogy a közösséggel együttmúködve tovább lehet fejleszteni a közszolgáltatásokat. Sőt, némely tevékenységeket a civileknek át (vissza) lehet adni, a feladatokat és a felelősséget is meg lehet velük osztani, és közösen sokkal innovatívabb és hatékonyabb megoldásokat lehet kitalálni. Ez a megállapítás a klasszikus értelemben vett szolgáltatók és a szolgáltatásokat igénybe vevők között fennálló viszonyokra régóta érvényes. Ha a rendészetet állami szolgáltatásként fogjuk fel - márpedig a közösségi rendészet filozófiája egyértelmúen emellett foglal állást -, akkor miért ne lehetne a Police Caféban mint speciálisan a biztonságteremtésre alkalmazott közösségi alkotótechnikában rejlő lehetőségeket sokkal jobban kiaknázni? A közösségi potenciál erejét használni kellene, különben hamar szétporlad. A rendőrvezetőknek is be kellene látniuk, hogy a biztonságteremtésben való civil részvétel valódi közösségi érdek, és haszna már rövid távon is megtérül.

\footnotetext{
54 Ezt a véleményt és az ügy iránti hasonlóan szenvedélyes elkötelezettségéből adódó biztatást ezúton is köszönöm Gáspár Mátyásnak.
} 


\section{IRODALOMJEGYZÉK}

Cserép Attila - Molnár Katalin (2005): Egy helyi közösségi rendőrségi projekt kezdeti lépései. Magyar Rendészet, 5. évf. 2. sz. 99-119.

Gaál Gyula - Molnár Katalin (2013): Ami elromolhat, az el is romlik? A média szerepe a biztonságos, élhető közösségek formálásában. In Gaál Gyula - Hautzinger Zoltán szerk.: Pécsi Határőr Tudományos Közlemények XVI. Pécs. 131-140.

Gaál Gyula - Molnár Katalin (2014): Másképpen a biztonságról - Police Café Pécs. Belügyi Szemle, 62. évf. 11. sz. 101-114.

Gaál, Gyula - Molnár, Katalin (2017): About the Safe Community. Jura, 23. évf. 1. sz. 58-63.

Gaál, Gyula - Molnár, Katalin (2015): Police Café Pécs - innovative Consultation of Police and Civilians about Security. Policajná Teória a Prax. Ročník, Vol. 23. No. 4. 71-78.

Fenyvesi Éva (2012): Stakeholder analízis. DOI: https://doi.org/10.13140/RG.2.2.36668.33920

Krémer Ferenc (2011): A biztonság intézménye és a rendőrség. Replika, Intézményes világ, 1. sz. 216-220.

Krémer Ferenc (2009): A (köz)biztonság jelentéséhez. Rendészeti Szemle, 2. sz. 62-90.

Krémer Ferenc (2018): Az élhetö társadalom, a biztonság meg a rendőrség. Kézirat. 16-19.

Mccarthy, Thomas (1980): Kritik der Verständigungsverhältnisse. Frankfurt, Suhrkamp Verlag.

Molnár Katalin (2019): A Police Café hatása a rendőrség és a közösségek kapcsolatára. 1. rész Kérdőíves felmérés. In Hegedűs Judit szerk.: Magatartástudományi kutatások a rendészeti képzés megújitása érdekében. Budapest, Dialóg Campus Kiadó.

Molnár Katalin - Uricska Erna (2018): An Efficient Method for Improving the Partnership between the Police and the Community. Special Conference Edition Nr. 4 of the European Law Enforcement Research Bulletin. Editors: D. Nogala, T. Görgen, J. Jurczak, B. Meszaros, P. Neyroud, L.G. Pais, B. Vegrichtova. No SCE 4. Forrás: https://bulletin.cepol.europa.eu/index.php/bulletin/article/ view/338/294 (2019. 07. 01.)

Molnár Café Kata (2019): Rendôrkávéházi élményeim. Police Café blogkönyv. Budapest, Rejtjel Kiadó.

Molnár Katalin - Tamási Zsolt (2019): A rendőrség közösséggel való kapcsolatának javítási lehetőségei. Belügyi Szemle, 67. évf. 4. sz. 35-56.

Vitale, Alex S. (2017): The End of Policing. London, Verso Books.

Walklate, Sandra (2001): Personal safety. In McLaughlin, Eugene and Muncie, John eds.: The Sage Dictionary of Criminology. New Delhi SAGE Publication, London, Thousend Oaks.

\section{Internetes források}

http://jozsefvaros.hu/hir/1510/jozsefvarosban_indult_el_a_police_cofee/ (2019. 07. 01.)

http://policecafe.hu/blog/ (2019. 07. 01.)

http://policecafe.hu/diak-police-cafe-kiskunhalason/ (2019. 07. 01.)

http://policecafe.hu/eloszor-masodszor-kiskunhalas-harmadszor/ (2019. 07. 01.)

http://policecafe.hu/jarasi-kozbiztonsagi-egyezteto-forum-es-police-cafe-bolyban-es-sasdon/ (2019. 07. 01.)

http://policecafe.hu/kepgaleria/ (2019. 07. 01.)

http://policecafe.hu/kommunikacios-potora-avagy-a-megszemelyesitett-korzeti-megbizotti-szabalyzat/ (2019. 07. 01.)

http://policecafe.hu/media/ (2019. 07. 01.)

http://policecafe.hu/michelangelo-es-a-rendorok-police-cafe-zarorak/ (2019. 07. 01.)

http://policecafe.hu/mikulas-napi-meglepetes-roma-police-cafe-kiskunhalason/ (2019. 07. 01.)

http://policecafe.hu/morczy-cafe-i-ii-iii-kell-egy-csapat/ (2019. 07. 01.)

http://policecafe.hu/onkiszolgalo-police-cafe-kiskunmajsan-az-elso-police-cafe-kepeslapom/ (2019. 07. 01.) 
http://policecafe.hu/police-cafe-extra-10-mikulas-napi-meglepetes-ii-becsben-is-a-szomszedom-arendor/ (2019. 07. 01.)

http://policecafe.hu/police-cafe-extra-14-ketnyelvu-parbeszed-a-meg-biztonsagosabb-zugloert/ (2019. 07. 01.)

http://policecafe.hu/police-cafe-extra-15-konyvajanlo/ (2019. 07. 01.)

http://policecafe.hu/police-cafe-extra-5-hogyan-hat-a-rendorkave/ (2019. 07. 01.)

http://policecafe.hu/police-cafe-extra-6-ujabb-cafe-kepeslap/ (2019. 07. 01.)

http://policecafe.hu/police-cafe-extra-9-halas-cafe-kepeslap-jarasi-kozbiztonsagi-egyezteto-forummaskent-immar-bacs-kiskunban-is/ (2019. 07. 01.)

http://policecafe.hu/police-cafe-liget/ (2019. 07. 01.)

http://policecafe.hu/police-cafe-pecs-budapest-2-1/ (2019. 07. 01.)

http://policecafe.hu/police-cafe-pecs-par-orara-ujra-nyitva/ (2019. 07. 01.)

http://policecafe.hu/rendorkavehazak/ (2019. 07. 01.)

http://policecafe.hu/szervezetfejleszto-kavehazat-nyitottak-egy-zugloi-iskolaban/ (2019. 07. 01.)

http://policecafe.hu/vedjegy-police-cafe-alapelvek/ (2019. 07. 01.)

http://policecafe.hu/zuglo-folytatja-a-masodik-police-cafe-kepeslapom/ (2019. 07. 01.)

www.ksh.hu/docs/hun/xstadat/xstadat_eves/i_wdsd003b.html (2019. 07. 01.)

www.nyelvilektoralas.hu/wp-content/uploads/2012/05/Police-Caf\%C3\%A9-P\%C3\%A9cs-

\%E2\%80\%93-innovative-consultation-of-police-and-civilians-about-security.pdf (2019. 07. 01.)

www.nyilvantarto.hu/hu/statisztikak (2019. 07. 01.)

www.theworldcafe.com/global-impact/ (2019. 07. 01.)

www.zknp.hu/buszkek-vagyunk-ra/ (2019. 07. 01.)

www.zuglo.hu/elismertek-a-munkajukat-17/ (2019. 07. 01.)

www.zknp.hu/szomszedom-a-rendor-program/ (2019. 07. 01.)

https://bulletin.cepol.europa.eu/index.php/bulletin/article/view/338/294 (2019. 07. 01.)

https://eucpn.org/events/european-crime-prevention-award-ecpa-and-best-practice-conference-bpc (2019. 07. 01.)

https://jura.ajk.pte.hu/JURA_2017_1.pdf (2019.07.01.)

https://tovabbkepzes.bmkszf.hu/\#!login (2019. 07. 01.)

www.cepol.europa.eu/ (2019. 07. 01.)

www.google.hu/intl/hu/forms/about/ (2019. 07. 01.)

\section{Jogforrás}

26/2015. (XII. 9.) ORFK utasítás a körzeti megbízotti szabályzatról

\section{ABSTRACT}

\section{The Effect of Police Cafés on the Relationship between the Police and the Community - Part 2: Interview Analysis}

MOLNÁR Katalin

The history of the Police Café methodology in Hungary has its 5th anniversary this year. More people are eager to know whether there are any effects of the events for the relationship between the Police and the community, and common local safety. In order to get a clear picture about how the participants themselves of the Cafés consider the Cafés and their effects, I carried out a survey about the opinion of 121 participants of 27 Cafés in Hungary between 2017 and 2018. 
The locations of the research were three towns in Baranya County, nine towns in Bács-Kiskun County and 8 precincts of Zugló, District 14th, Budapest. This present paper is the second part of the findings of the questionnaire-based survey in which 7-7 interviews were analysed of the participating police personnel and the civilians.

Keywords: community, police, Police Café, problem solving, World Café 